\title{
Spatial and temporal variability in the ratio of trace gases emitted from biomass burning
}

\author{
T. T. van Leeuwen and G. R. van der Werf \\ VU University Amsterdam, Faculty of Earth and Life Sciences, Department of Hydrology \\ and Geo-environmental Sciences, Amsterdam, The Netherlands
}

Received: 27 August 2010 - Published in Atmos. Chem. Phys. Discuss.: 11 October 2010

Revised: 25 February 2011 - Accepted: 20 March 2011 - Published: 19 April 2011

\begin{abstract}
Fires are a major source of trace gases and aerosols to the atmosphere. The amount of biomass burned is becoming better known, most importantly due to improved burned area datasets and a better representation of fuel consumption. The spatial and temporal variability in the partitioning of biomass burned into emitted trace gases and aerosols, however, has received relatively little attention. To convert estimates of biomass burned to trace gas and aerosol emissions, most studies have used emission ratios (or emission factors (EFs)) based on the arithmetic mean of field measurement outcomes, stratified by biome. However, EFs vary substantially in time and space, even within a single biome. In addition, it is unknown whether the available field measurement locations provide a representative sample for the various biomes. Here we used the available body of EF literature in combination with satellite-derived information on vegetation characteristics and climatic conditions to better understand the spatio-temporal variability in EFs. While focusing on $\mathrm{CO}, \mathrm{CH}_{4}$, and $\mathrm{CO}_{2}$, our findings are also applicable to other trace gases and aerosols. We explored relations between EFs and different measurements of environmental variables that may correlate with part of the variability in EFs (tree cover density, vegetation greenness, temperature, precipitation, and the length of the dry season). Although reasonable correlations were found for specific case studies, correlations based on the full suite of available measurements were lower and explained about 33\%, 38\%, 19\%, and 34\% of the variability for respectively $\mathrm{CO}, \mathrm{CH}_{4}, \mathrm{CO}_{2}$, and the Modified Combustion Efficiency (MCE). This may be partly due to uncertainties in the environmental variables, differences in measurement techniques for EFs, assumptions on the ratio between flaming and smoldering combustion, and incomplete information on the location and timing of EF
\end{abstract}

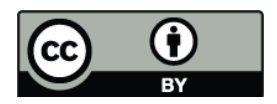

Correspondence to: T. T. van Leeuwen (thijs.van.leeuwen@falw.vu.nl) measurements. We derived new mean EFs, using the relative importance of each measurement location with regard to fire emissions. These weighted averages were relatively similar to the arithmetic mean. When using relations between the environmental variables and EFs to extrapolate to regional and global scales, we found substantial differences, with for savannas $13 \%$ and $22 \%$ higher $\mathrm{CO}$ and $\mathrm{CH}_{4} \mathrm{EFs}$ than the arithmetic mean of the field studies, possibly linked to an underrepresentation of woodland fires in EF measurement locations. We argue that from a global modeling perspective, future measurement campaigns could be more beneficial if measurements are made over the full fire season, and if relations between ambient conditions and EFs receive more attention.

\section{Introduction}

Although biomass burning is one of the most ancient forms of anthropogenic atmospheric pollution, its importance for atmospheric chemistry has only been recognized since the late seventies (Radke et al., 1978; Crutzen et al., 1979). Interest in this topic grew when studies suggested that for several trace gases and aerosol species, biomass burning emissions could rival fossil fuel emissions (Seiler and Crutzen, 1980; Crutzen and Andreae, 1990), and that these vegetation fires could affect large parts of the world due to longrange transport processes (Andreae, 1983; Fishman et al., 1990; Gloudemans et al., 2006). During the last two decades biomass burning has received considerable interest, leading for example to the realization that vegetation fires impact 8 out of 14 identified radiative forcing terms (Bowman et al., 2009), contribute to interannual variability (IAV) in growth rates of many trace gases (Langenfelds et al., 2002), and influence human health and plant productivity downwind of fires through enhanced ozone and aerosol concentrations (e.g. Sitch et al., 2007). 
To assess the atmospheric impact of biomass burning quantitatively, accurate emissions estimates of trace gases and aerosols are required. Crucial parameters include burned area, fuel consumption, and the emission factor (EF), usually defined as the amount of gas or particle mass emitted per $\mathrm{kg}$ of dry fuel burned, expressed in units of $\mathrm{g} \mathrm{kg}^{-1}$ dry matter (DM) (Andreae and Merlet, 2001).

Pioneering experiments to characterize fire emissions were conducted in South America (Crutzen et al., 1979), Africa (Delmas, 1982), and Australia (Ayers and Gillett, 1988). In the beginning of the 1990s, the experiments of these individual groups were followed by a number of large international biomass burning experiments in various ecosystems throughout the world. These included the Southern Africa Fire-Atmosphere Research Initiative (SAFARI 92 and SAFARI 2000) in southern Africa (Lindesay et al., 1996; Swap et al., 2002), Dynamique et Chimie Atmosphérique en Forêt Equatoriale-Fire of Savannas (DECAFE-FOS) in West Africa (Lacaux et al., 1995), Transport and Atmospheric Chemistry Near the Equator-Atlantic (Trace-A) over Brazil, southern Africa, and the South Atlantic (Fishman et al., 1996), Fire Research Campaign Asia-North (FireSCAN) in central Siberia (FIRESCAN Science Team, 1996), and Smoke, Clouds, and Radiation-Brazil (SCAR-B) in Brazil (Kaufman et al., 1998).

These coordinated studies and numerous independent smaller investigations have resulted in a large body of information on emission characteristics. Several summaries of experimental EF data were given (e.g. Andreae, 1993; Delmas et al., 1995; Akagi et al., 2010). The most extensive and frequently used summary is given by Andreae and Merlet (2001), in which all the available data on fire emission characteristics for a large number of chemical species was synthesized into a consistent set of units. The measurements were stratified by biome type or fire use; tropical forest fires (in general fires used in the deforestation process), savanna and grassland fires, extratropical forest fires, biofuel burning, charcoal making, charcoal burning, and the burning of agricultural residues. The database is updated annually (M.O. Andreae, personal communication, 2009) and we will refer to this as A\&M2001-2009 in the remainder of this paper.

Including fire processes in dynamic global vegetation models (DGVM) and biogeochemical models led to a better understanding of the spatio-temporal variability in fuel loads and fire processes. For example, annual global burned area estimates (Giglio et al., 2006, 2010) and global emissions estimates according to the Global Fire Emissions Database (GFED; van der Werf et al., 2006, 2010) are decoupled on an annual timescale because most burned area occurs in savanna-type ecosystems with relatively low fuel loads, while the smaller areas that burn in forested ecosystems result in higher emissions per unit area burned due to fuel loads that are at least one order of magnitude larger.
New burned area products (L3JRC (Tansey et al., 2007), MODIS (Roy et al., 2008; Giglio et al., 2010), GLOBCARBON (Plummer et al., 2006)) allow for a better characterization of the timing and locations of fire, although the quality of these burned area products varies and they may have difficulties in capturing small fires (Chang et al., 2009; Roy and Boschetti, 2009; Giglio et al., 2010). When accounting for errors in transport and chemistry as well as uncertainties in satellite retrievals of trace gases and aerosols, combining bottom-up (such as GFED) and top-down methods potentially allows for an assessment of the magnitude of emissions as well as their spatio-temporal variability (Arellano et al., 2004; Edwards et al., 2004; Gloudemans et al., 2006; Kopacz et al., 2010). This requires a thorough understanding of the relations between biomass combusted and emission of the trace gases or aerosols that are used as top-down constrains, most often CO.

Although our knowledge of the spatial and temporal variability of fire substantially increased in the last decade due to new satellite information, the total amount of biomass combusted, and especially the partitioning of combusted carbon (C) into different combustion products, is improving but still uncertain. To date, most large-scale studies have used the average EFs provided by A\&M2001-2009. EFs, however, show large variability, mainly due to differences in fuel type and composition, burning conditions, and location (Andreae and Merlet, 2001; Korontzi et al., 2003). Even though EFs may vary in time and space, this variability is usually not taken into account in large-scale emissions assessments except for variations due to vegetation type (in general all savanna fires, all tropical forest fires, all extratropical forest fires, and all agricultural waste burning fires have their own, averaged, EFs). In addition to the lack of representation in spatio-temporal variability, the often-used average EFs may have limitations because it is not known whether they are based on a representative sample of a specific vegetation type.

In the literature only a few papers on regional emissions estimates considered seasonal and/or spatial variability of EFs. Hoffa et al. (1999) computed fire emissions in Zambian grasslands and woodlands using PGREEN, defined as the proportion of green grass biomass to total (green+dead) grass biomass. Ito and Penner (2005) applied three different EF scenarios that accounted for both seasonal and spatial variability. Both studies confirmed that a spatial and temporal varying $\mathrm{EF}$ can have a significant impact on regional emissions estimates.

Here we evaluated existing information on EFs, based on an extensive database of field measurements (A\&M20012009), and systematically explored several environmental variables that may be related to the spatial and temporal variability in EFs. Data on fraction tree cover (FTC), precipitation, temperature, Normalized Difference Vegetation index (NDVI, a measure of vegetation greenness or productivity), and length of the dry season were used to develop 
relations with the EFs for different vegetation types. We focused on $\mathrm{CO}, \mathrm{CH}_{4}$, and $\mathrm{CO}_{2}$. However, since the Modified Combustion Efficiency (MCE, defined as the amount of $\mathrm{C}$ released as $\mathrm{CO}_{2}$ divided by the amount of $\mathrm{C}$ released as $\mathrm{CO}_{2}$ plus $\mathrm{CO}$ (Yokelson et al., 1996)) has been used as an effective predictor for the emission of smoke gas composition from biomass fires (e.g., Ward et al., 1996; Sinha et al., 2003; Yokelson et al., 2003) and for certain aerosol species and characteristics (e.g., Christian et al., 2003; McMeeking et al., 2009; Janhäll et al., 2010), our findings on CO and $\mathrm{CO}_{2}$ EFs can be used to better understand emissions of other trace gases and aerosols as well. We restricted our analysis to in situ measurements due to the focus on spatio-temporal variability as a result of variability in vegetation and climatic conditions; laboratory measurements of EFs were not taken into account. We present new weighted EFs for specific vegetation types, and indicate how future EF experiments could be more beneficial from a global modeling perspective.

\section{Fire processes}

To facilitate the description of the main factors that influence the EF of different trace gases (Sect. 2.2), we start with a brief summary of the combustion process (Sect. 2.1). For more detailed information the reader is referred to Chandler et al. (1983), Lobert and Warnatz (1993), and Yokelson et al. $(1996,1997)$.

\subsection{The combustion process}

The combustion of the individual fuel elements proceeds through a sequence of stages (ignition, flaming, smoldering, and extinction), each with different chemical and physical processes that result in different emissions.

The initial ignition is the phase before a self-sustaining fire can start, and it depends on both fuel (size, density, water content) and environmental (temperature, relative humidity, wind speed) factors whether the fuel is ignited or not. Once the fuel is sufficiently dry, combustion can proceed from the ignition phase to the flaming phase. It starts with thermal degradation, in which water and volatile contents of the fuel are released, and is followed by the thermal cracking of the fuel molecules (pyrolytic step); high-molecular compounds are decomposed to char (less volatile solids with high C content), tar (molecules of intermediate molecular weight), and volatile compounds. When diluted with air, a flammable mixture may form. Many different compounds are produced during this phase, particularly $\mathrm{CO}_{2}$ and $\mathrm{H}_{2} \mathrm{O}$.

After most volatiles have been released and the rate of the pyrolysis slows down, less flammable compounds are produced; the flaming combustion ceases, and the smoldering phase begins. Smoldering combustion is a lowertemperature process compared to flaming combustion emitting large amounts of incompletely oxidized compounds (e.g.
$\mathrm{CO}$ ), and can proceed for days, even under relatively high moisture conditions. The slower rate of pyrolysis results in lower heat production and therefore in a lower decomposition rate, until the process terminates (extinction phase). The most common causes of extinction are a physical gap in the fuels that prevents sufficient heat transfer to additional fuels, rainfall, or fire spread into wet fuels.

The combustion processes described above are somewhat simplified, and in most fires all of these processes occur simultaneously in different parts of the fuel bed. For real-time open vegetation fires, different factors that influence the combustion process and which may change over time (e.g. meteorological conditions, differences in aboveground biomass density, topography) also need to be considered. The amount of substances emitted from a given fire and their relative proportions are determined to a large extent by the ratio of flaming to smoldering combustion, which is related to the combustion efficiency (CE), defined as the fraction of the fuel $\mathrm{C}$ burned converted to $\mathrm{CO}_{2}$.

\subsection{Factors influencing the EF}

The exact physical relations between environmental variables and EFs are not well understood, although recent laboratory studies have aimed to quantify how, for example, moisture content impacts EFs (e.g. Chen et al., 2010). Qualitatively, important parameters that partly govern the flaming/smoldering ratio and thus EFs include vegetation characteristics, climate, weather, topography, and fire practices.

A variable that may affect both the behavior and the emissions of a fire is the water content of the vegetation. The water content partly determines whether a plant or tree can ignite and what the CE will be. Water in plants or trees has the capability to either stop a fire completely or to slow down the burning process (to a low smoldering stage). However, also wet fuels can ignite if a sustained ignition source is applied. For instance, crown fires spread at high rates with large flames burning fresh foliage with high moisture content.

Other fuel characteristics related to vegetation are the size, density, and the spacing of the fuels. Some studies (Bertschi et al., 2003; McMeeking et al., 2009) suggested that combustion completeness (CC), defined as the fraction of biomass exposed to a fire that was actually consumed (or volatilized) in a fire, is impacted more by fuel spacing than its water content. It is likely that fuel size and density are important in driving variability in EFs as well. Because fuel has to be heated to ignition temperature, small low-density fuel particles are more easily ignited than larger high-density particles. Once burning, the rate of heat production for smaller particles is higher than for larger particles, and therefore smaller particles are also capable of sustaining flaming combustion and supporting the burning of larger particles. In general, grass fuels in savannas have a large surface to volume ratio, are more easily pyrolized, and therefore burn largely in the flaming phase, while stems and coarse litter that burn in 
forest fires are not as well oxidized and burn more in the smoldering phase. However, with an efficient heat transfer between fuel elements even large logs in deforestation fires can be consumed mostly by flaming combustion (Christian et al., 2007; McMeeking et al., 2009).

Climate plays an important role in the existence and settlement of vegetation, and thus determines the availability of fire fuel (Lobert and Warnatz, 1993). Fire frequency and the fire season are also partly determined by climatic factors. Weather has a more short-term impact on fire. Temperature, precipitation, and wind speed are factors that partly determine the occurrence of fires as well as their behavior, especially the CE. Temperature may affect the fire probability and ignition due to its effect on fuel moisture. Precipitation is capable of inhibiting, completely stopping, or preventing a fire. Wind can have an effect on the spread rate of a fire, as fires usually propagate in two different directions; with the wind (heading fires) and into the wind (backing fires). The local topography can also change the burning behavior of a fire; heat rises and an upslope fire therefore achieves better heat transfer from the burning fuels to the unburned fuels. If all other conditions are equal, this leads to fires that spread faster.

In the tropics and subtropics, fire is mainly a human-driven process. We expect that regional variations in fire practices influences EFs, especially in agricultural fires and fires used in the deforestation process. Slash and burn fires, for example, are different from the burning of fuels that have been mechanically piled together into windrows and may burn more intensely. This practice requires heavy machinery and is therefore limited to regions with more capital, for example the southern part of the Amazon where forests are cleared for soy production, amongst others (Morton et al., 2006).

In summary, both the combustion process and its interrelationship with the environment are very complicated. At present, literature focusing on how environmental variables impact EFs from real fires is limited and data from laboratory studies is often conflicting and inconclusive (R. J. Yokelson, personal communication, 2011). Nevertheless, empirical relationships between satellite observables and EFs may exist and are further explored here.

\section{Literature database of EF measurements}

\subsection{Introduction}

We used the EF database for different vegetation types that was compiled by A\&M2001-2009. The database consists of EFs measured during individual experiments, as well as during large international measurement campaigns. The database includes both field data (sampled on the ground or from aircraft) and laboratory measurements. We excluded laboratory measurements in our analyses because the focus of our work is on EF variability and the role of local (climatic) conditions, which are better represented by EF measurements in the field. In addition, laboratory measurements may not be fully representative of burning conditions in the field; it is for example impractical to burn a diverse suite of large diameter tropical logs in the lab (Yokelson et al., 2008). In the work of A\&M2001-2009, laboratory measurements were also excluded for calculating biomeaveraged $\mathrm{EFs}$ for $\mathrm{CO}, \mathrm{CH}_{4}$, and $\mathrm{CO}_{2}$.

Most of the EFs in the database of A\&M2001-2009 are measured using the $\mathrm{C}$ mass balance (CMB) method (Ward et al., 1979; Radke et al., 1990). The underlying premise of this method is that all $\mathrm{C}$ combusted in a fire is emitted into measurable portions in five forms: $\mathrm{CO}_{2}, \mathrm{CO}, \mathrm{CH}_{4}$, non-methane hydrocarbons (NMHC), and particulate $\mathrm{C}$ in smoke particles. The EF of a species is then calculated from the ratio of the mass concentration of those species to the total carbon concentration emitted in the plume. To convert the EF to $\mathrm{g} \mathrm{kg}^{-1}$ DM of fuel burned, the data need to be multiplied with the carbon content of the fuel. A\&M2001-2009 adopted a C content of $45 \%$ when this information was not given in literature cited. However, a detailed study of Susott et al. (1996) suggests a global average $\mathrm{C}$ fraction for biomass closer to $50 \%$, with a considerable range, which would indicate an additional $\sim 10 \%$ uncertainty in addition to other uncertainties.

When the emission data were given as molar emission ratios, A\&M2001-2009 used the molecular weights of the trace and reference species to calculate the EF. Molar emission ratios can be obtained by dividing excess trace species concentrations measured in a fire plume by the excess concentration of a simultaneously measured reference gas (most often $\mathrm{CO}_{2}$ ). If the $\mathrm{EF}$ of the reference species was not provided, the mean EF for the specific type of fire was used.

With the A\&M2001-2009 database as a starting point, we compiled all EFs and searched the literature for accompanying ancillary data such as measurement location and timing. We then expanded the database to include location-specific parameters related to vegetation type and climate of each measurement. We focused on the EFs of $\mathrm{CO}_{2}, \mathrm{CO}$, and $\mathrm{CH}_{4}$ because these gases were measured during most campaigns, and the $\mathrm{EF}$ of $\mathrm{CO}_{2}$ and $\mathrm{CO}$ can be used to calculate the MCE, which can be used to predict EFs of other species (e.g., Ward et al., 1996; Sinha et al., 2003; Yokelson et al., 2003).

\subsection{Available EF data}

Figure 1 provides an overview of the locations where groundand aircraft $\mathrm{EF}$ measurements were conducted for $\mathrm{CO}$ and $\mathrm{CO}_{2}$, with a background of mean annual fire $\mathrm{C}$ emissions. Fire emissions were taken from the Global Fire Emission Database (GFED) version 3.1 (Giglio et al., 2010; van der Werf et al., 2010). GFED consists of $0.5^{\circ} \times 0.5^{\circ}$ gridded monthly parameters; burned area, fuel loads, CC, and fire $\mathrm{C}$ losses. Fire emissions were estimated based on burned area (Giglio et al., 2010) in combination with the CarnegieAmes-Stanford Approach (CASA) biogeochemical model to 


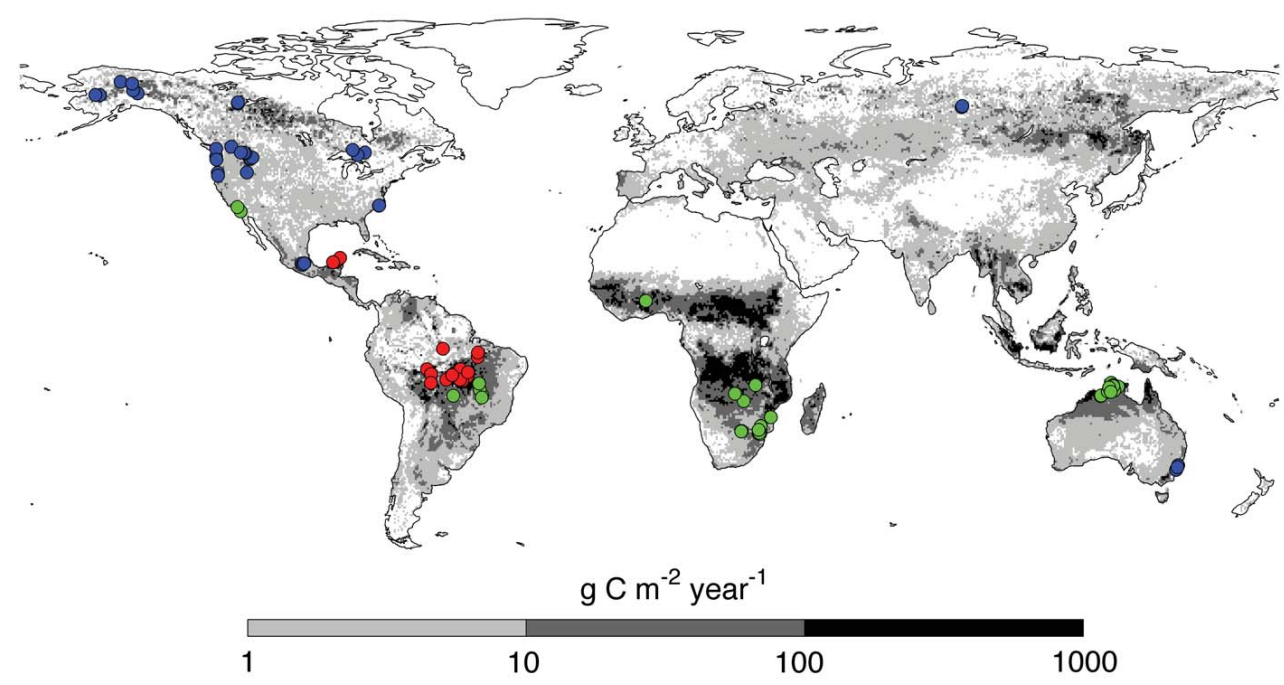

Fig. 1. Locations where simultaneous $\mathrm{CO}$ and $\mathrm{CO}_{2}$ EFs were measured. Locations were stratified by biome following A\&M2001-2009; savanna and grassland (green), tropical forest (red), and extratropical forest (blue). Background map shows annual GFED3.1 fire emissions in $\mathrm{g} \mathrm{C} \mathrm{m}^{-2}$ year $^{-1}$, averaged over 1997-2008, and plotted on a log scale.

calculate fuel consumption. See van der Werf et al. (2010) for more information.

Most locations with both $\mathrm{CO}$ and $\mathrm{CO}_{2}$ EF measurements are in North America, the arc of deforestation in the Brazilian Amazon, southern Africa (South Africa and Zambia), and northern Australia (Fig. 1). While these areas are all major biomass burning regions, several other important regions lack measurements. These include Central Africa (e.g. Congo, Angola, but also regions further north such as Chad and southern Sudan), Siberia, Indochina, and Indonesia, although laboratory studies for Indonesian fuel samples exist (Christian et al., 2003). Most of these missing regions likely have relatively high rates of emissions of reduced gases compared to sampled regions; more woodland burning in Central Africa compared to southern Africa where most savanna measurements were made, more ground fires in boreal Asia (Wooster and Zhang, 2004) compared to boreal North America where most extratropical EFs were measured, and moister conditions and more peat burning in Indonesia compared to South America where most deforestation fire EF measurements were made. On the other hand, most measurements in Australia were made in the relatively moist part in the North while fires burning in the more arid interior have not been sampled.

To highlight the large variability in EFs, we plotted $\mathrm{CH}_{4}$ EFs against the molar MCE (based on $\mathrm{CO}$ and $\mathrm{CO}_{2} \mathrm{EFs}$ ) in Fig. 2 for three different biomes. The biome-averaged EF values of A\&M2001-2009 are also shown. In general, EFs in savannas and grasslands show high MCEs and a relatively low EF for $\mathrm{CH}_{4}$, mainly because burning mostly takes place in the flaming phase. Tropical forest measurements on the other hand, show lower MCEs and higher values for the $\mathrm{EF}$ of $\mathrm{CH}_{4}$, because these fires burn predominantly in the smoldering phase. This is also the case for the extratropical forest measurements, although here the values are more variable. The correlation coefficient $(r)$ between MCE and $\mathrm{CH}_{4}$ for all these in situ measurements was $-0.71\left(\mathrm{EF}_{\left(\mathrm{CH}_{4}\right)}=-85.889 \times \mathrm{MCE}+85.278\right)$, and correlation coefficients for the different vegetation types were $-0.80\left(\mathrm{EF}_{\left(\mathrm{CH}_{4}\right)}=-61.447 \times \mathrm{MCE}+61.142\right)$, $-0.81 \quad\left(\mathrm{EF}_{\left(\mathrm{CH}_{4}\right)}=-104.551 \times \mathrm{MCE}+104.590\right), \quad$ and $-0.52\left(\mathrm{EF}_{\left(\mathrm{CH}_{4}\right)}=-59.992 \times \mathrm{MCE}+60.967\right)$ for savanna and grasslands, tropical forest, and extratropical forest, respectively. Two extratropical forest measurements (Cofer et al., 1998: $\mathrm{MCE}=0.78, \mathrm{EF} \mathrm{CH}_{4}=4.5$; Hobbs et al., 1996: $\mathrm{MCE}=0.81, \mathrm{EF} \mathrm{CH}_{4}=16.2$ ) were excluded from this graph for clarity, but they were taken into account to calculate the correlation coefficient.

Although lowering the number of EF studies in general decreases the correlation coefficient, several individual studies focusing on a selected number of measurements found higher correlation coefficients than the ones reported above. Yokelson et al. (2003) found a correlation coefficient of $-0.93\left(\mathrm{EF}_{\left(\mathrm{CH}_{4}\right)}=-48.522 \times \mathrm{MCE}+47.801\right)$ for 8 African savanna fires. Korontzi et al. (2003) also found higher correlations and a slightly different slope for the regression of southern African savanna measurements; grasslands had a correlation coefficient of $0.94\left(\mathrm{EF}_{\left(\mathrm{CH}_{4}\right)}=-43.63 \times \mathrm{MCE}+42.951\right)$ and for woodlands a correlation of $0.98\left(\mathrm{EF}_{\left(\mathrm{CH}_{4}\right)}=-58.214 \times \mathrm{MCE}\right.$ +56.710 ) was found. Both vegetation types combined gave an overall correlation of 0.94 , and a trend line of $\mathrm{EF}_{\left(\mathrm{CH}_{4}\right)}=-47.948 \times \mathrm{MCE}+47.068$. 


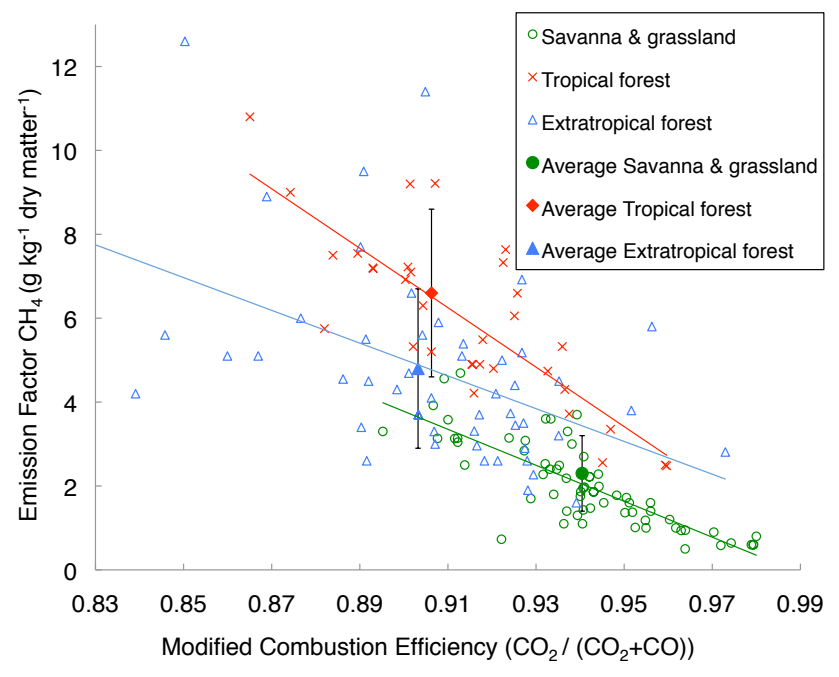

Fig. 2. Methane $\left(\mathrm{CH}_{4}\right)$ EFs and the molar-based modified combustion efficiency (MCE) for all available measurements, the biomeaveraged values presented in A\&M2001-2009, and regression lines. The error bar indicates the standard deviation as reported in A\&M2001-2009. Regression coefficients for the different biomes can be found in Section 3.2.

For the tropical forest biome, Yokelson et al. (2008) found a correlation coefficient of 0.72 for 9 fire-averaged MCEs and $\mathrm{CH}_{4} \mathrm{EFs}$. The slope of this regression was more gentle $\left(\mathrm{EF}_{\left(\mathrm{CH}_{4}\right)}=-47.105 \times \mathrm{MCE}+48.555\right)$ than the slope for this biome using all measurements in the A\&M2001-2009 database. In older work, comparisons between the $\mathrm{CE}$ (which correlates well with the $\mathrm{MCE}$ ) and $\mathrm{CH}_{4} \mathrm{EFs}$ were presented. Ward et al. (1992) showed a correlation of 0.96 and a slope of $\mathrm{EF}_{\left(\mathrm{CH}_{4}\right)}=-82.1 \times \mathrm{CE}+78.6$ for a regression of $18 \mathrm{de}-$ forestation fires in Brazil. We are not aware of any recent comparisons between $\mathrm{MCE}$ and $\mathrm{EF} \mathrm{CH}_{4}$ for fires in the extratropical forest biome, but in older work of e.g. Ward and Hardy (1991) and Hao and Ward (1993), an overall higher correlation $(r>0.8)$ was found for extratropical forest measurements. The slope of the regression lines of these individual studies was more gentle than the slope we found for the whole dataset. Lab experiments (Christian et al., 2003; McMeeking et al., 2009; Burling et al., 2010) also show overall higher correlations between MCE and EF $\mathrm{CH}_{4}$ than our results for all data for the different vegetation biomes combined.

Overall, higher correlation coefficients and flatter slopes for the EF $\mathrm{CH}_{4}$ and MCE relationship were found for individual studies focusing on a relatively small number of EF measurements, compared to the whole EF database of A\&M2001-2009. Possible explanations for these differences between the whole dataset compared to individual studies are discussed in Sect. 4. Individual studies (e.g. Hao and Ward, 1993) have shown that the linear relationships between the MCE and $\mathrm{EF} \mathrm{CH}_{4}$ are quite different for individ- ual biomes, for reasons not fully understood. This is also apparent from Fig. 2; the slope and intercept of the savanna and extratropical forest biome compared very well, but the regression line of $\mathrm{CH}_{4} \mathrm{EFs}$ and their MCE derived for tropical forest biome showed a steeper slope and larger intercept. Extratropical forest EF measurements showed more scatter than those from the savanna and grassland and tropical forest biomes, which led to a relatively low correlation coefficient when combining all data.

The large variability (even within biomes) apparent from Fig. 2 may be partly explained by the different environmental variables that we described in Sect. 2.2. One is related to the timing of the measurement, and thus to weather conditions during the fire (e.g., Korontzi et al., 2003). Fires in savannas and tropical forest areas usually burn during the late dry season, when fuel moisture is in general at minimum. Prescribed burning in tropical savannas on the other hand is often exercised in the early part of the dry season, and is commonly advocated when fire is used as a land management tool. Early season burns are less intense and result in a smaller amount of vegetation consumed per unit area and - probably more important - lead to less damage to the soil compared to late season fires. Pastoralists burn extensively in the early dry season to stimulate regrowth of palatable grasses for their cattle; fire is used for rapid nutrient release prior to the new growing season by farmers, and early burning is used in national parks as a preventive measure against late dry season fires which tend to have higher intensities and are in general more destructive (Frost, 1996; Williams et al., 1998).

We explored the seasonal variation of the fire emissions for all EF data where a detailed description of the location and date of measurements was provided. To investigate whether the available measurements captured the fire seasonality we compared the number of EF measurements conducted in a specific biome with the seasonal variation in $\mathrm{C}$ emissions according to GFED3.1 (Fig. 3). Only the $0.5^{\circ} \times 0.5^{\circ}$ grid cells enclosing the locations where EF measurements were conducted for $\mathrm{CO}, \mathrm{CH}_{4}$, and $\mathrm{CO}_{2}$ were used, and the seasonal cycle in each grid cell was normalized to its peak fire month (PFM). Fig. 3a shows the seasonality of the number of EF measurements and the GFED3.1 fire emissions for all the EF measurement locations in the savanna and grassland biome for the PFM, and the months before and after the PFM. Results for the tropical forest biome are shown in Fig. $3 \mathrm{~b}$.

For EF measurement locations in the savanna biome, $46 \%$ of the total annual amount of $\mathrm{C}$ was emitted by fires in the PFM, and $78 \%$ when also including the month before and after the PFM. For the tropical forest biome, this was $66 \%$ and $84 \%$, respectively. The percentage of EF measurements conducted in the PFM was $23 \%$ for both the savanna and tropical forest biome, and respectively $71 \%$ and $88 \%$ when also including the month before and after the PFM. In other words, the current body of measurements have undersampled the peak fire month with especially the tropical forest fire measurements sampling earlier than desirable. Extratropical 


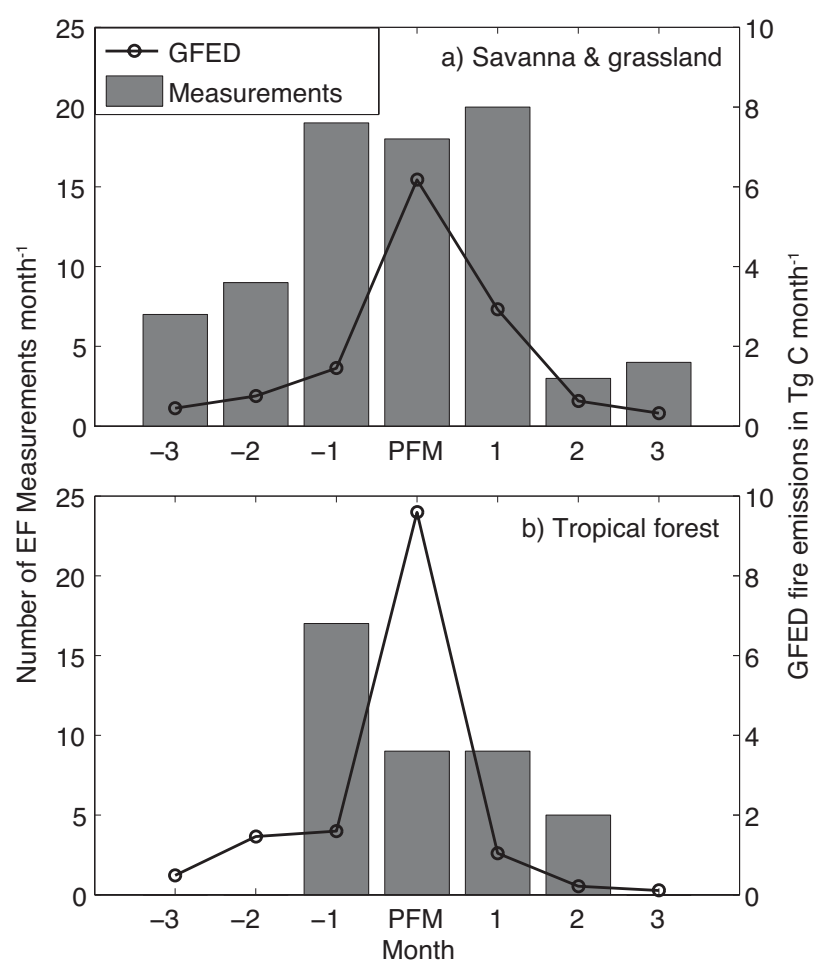

Fig. 3. Number of EF measurements (bars) and GFED3.1 fire emissions (lines) in $\mathrm{Tg} \mathrm{C}$ month $^{-1}$ for a 7 -month period centered around the peak fire month (PFM), for the (a) savanna and grassland and (b) tropical forest biome.

forest measurements were excluded from this analysis, because the fire season is much more variable from year to year compared to the tropics (Giglio et al., 2006).

\subsection{Environmental variables}

One of our main objectives was to model the variability in $\mathrm{CO}, \mathrm{CH}_{4}$, and $\mathrm{CO}_{2}$ EFs for coarse-scale grid cells $\left(0.5^{\circ} \times 0.5^{\circ}\right.$ or about $50 \times 50 \mathrm{~km}$ in the tropics $)$. For this, we compared all the EFs in the database with global monthly datasets of potentially relevant parameters (as described in Sect. 2.2); FTC, precipitation, temperature, NDVI, and the length of the dry season. These parameters were chosen since globally consistent information is available for a longer period of time, although the spatial and temporal resolution is relative coarse (typically $0.5^{\circ} \times 0.5^{\circ}$ and monthly data) and may not fully capture key regional variability. Specific local and regional factors that may have a large influence on the EF variability, like e.g. wind speed, were excluded due to a lack of reliable data.

We used the FTC product regridded to $0.5^{\circ} \times 0.5^{\circ}$ resolution for the year 2002 to represent the vegetation density and the ratio between herbaceous and woody fuels in the EF measurement locations. In the GFED modeling framework, FTC is the key control on the fraction coarse fuels that burn predominantly in the smoldering phase (e.g., stems, coarse woody debris) as opposed to fine fuels burning mostly in the flaming phase (leaves, grass, fine litter) in a grid cell. The FTC product was derived from the Vegetation Continuous Fields (VCF) collection which contains proportional estimates for vegetative cover types: woody vegetation, herbaceous vegetation, and bare ground (Hansen et al., 2003). The product was derived from seven bands of the MODerateresolution Imaging Spectroradiometer (MODIS) sensor onboard NASA's Terra satellite. The continuous classification scheme of the VCF product better captures areas of heterogeneous land cover than traditional discrete classification schemes.

The $1^{\circ} \times 1^{\circ}$ daily (1DD) Global Precipitation Climatology Project (GPCP) precipitation product (Huffman et al., 2001) was used to estimate the correlation of EFs with precipitation. This dataset is based on passive microwave measurements from the Special Sensor Microwave Imager (SSM/I), and infrared retrievals from the Geostationary Operational Environmental Satellite (GOES) and the Television InfraRed Observation Satellite (TIROS) Operational Vertical Sounder (TOVS). The monthly rainfall totals are corrected over some continental areas to match sparse ground-based observations, and at finer time scales the product relies exclusively on satellite-based precipitation estimates. We averaged the daily values to calculate a monthly value (mm month ${ }^{-1}$ ) for the years 1997-2008, the period of availability. For EF measurements conducted before the year 1997 , we used the monthly $2.5^{\circ} \times 2.5^{\circ}$ GPCPv 2.1 precipitation product (Adler et al., 2003), which is available from 1979 till present. Monthly averaged precipitation data for the years 1997-2008 were also used to calculate the mean annual precipitation (MAP). All data was regridded to $0.5^{\circ} \times 0.5^{\circ}$ resolution using linear interpolation. Since we explored large-scale relations between EFs and the monthly and mean annual precipitation only, we may miss variability related to synoptic scale precipitation.

Temperature data were derived from a climatology and an anomaly source. The climatological data were downloaded from the Climate Research Unit (CRU) website (http://www. cru.uea.ac.uk/). We used the CRU CL 1.0 Mean Monthly Climatology product, with a resolution of $0.5^{\circ} \times 0.5^{\circ}(\mathrm{New}$ et al., 1999). This dataset gives the mean monthly surface climate over global land areas, excluding Antarctica, and was interpolated from station data to $0.5^{\circ} \times 0.5^{\circ}$ for several variables. We then used the NASA GISS Surface Temperature Analysis (GISTEMP) as a source of temperature anomalies (Hansen et al., 1999). GISTEMP provides a measure of the global surface temperature anomaly with monthly resolution for the period since 1880 , when a reasonable global distribution of meteorological stations was established. Input data for the analysis, collected by many national meteorological services around the world, is the unadjusted data of the Global Historical Climatology Network (Peterson and Vose, 1997). Documentation of the 
GISTEMP analysis is provided by Hansen et al. (1999), with several modifications described by Hansen et al. (2001). We used the 1961-1990 anomalies with a $1200 \mathrm{~km}$ smoothing radius, which were downloaded from the NASA website (http://data.giss.nasa.gov/gistemp/maps/). The CRU climatology and GISTEMP anomalies were combined to estimate the monthly temperatures for the years 1967-2009. Monthly averaged temperature data for the years 1997-2008 were used to define the mean annual temperature (MAT).

The Normalized Difference Vegetation Index (NDVI) represents the amount of live green vegetation and its productivity, and may be a useful indication of vegetation characteristics (fuel abundance and also live fuel moisture conditions). Monthly Global Inventory Modelling and Mapping Studies (GIMMS) NDVI data with a $8 \times 8 \mathrm{~km}$ resolution (Tucker et al., 2005) were downloaded from the Global Land Cover Facility website (http://www.glcf.umd.edu/data/ gimms/). Different satellite series of NOAA's Advanced Very High Resolution Radiometer (AVHRR) were used for this NDVI record. The dataset consists of bi-monthly NDVI data for the years 1981 to 2006, which we averaged to monthly values. For EF measurements that were conducted before 1981 or after 2006, we used the monthly mean of the years 1981-2006.

The length of the dry season for the EF measurement locations was defined by counting the number of consecutive months in the 6-month period before the measurement was conducted with precipitation rates below $100 \mathrm{~mm} \mathrm{month}^{-1}\left(\mathrm{GPCP} 1^{\circ} \times 1^{\circ}\right.$ for the 1997-2008 period, and GPCPv2.1 $2.5^{\circ} \times 2.5^{\circ}$ for $\left.1979-1997\right)$. This parameter partly overlaps with the precipitation rates, but the added value lies in containing a memory of precipitation; it may be an indicator of the precipitation conditions before the month of the actual measurement. It may be especially valuable for estimating the moisture content of fuels with low surface to volume ratios such as stems, which often take more than one month to come in equilibrium with ambient moisture conditions (Bradshaw et al., 1984).

\subsection{Correlations between environmental variables and EFs}

In Table 1 the correlation coefficients between the environmental data and the EFs of $\mathrm{CO}, \mathrm{CH}_{4}, \mathrm{CO}_{2}$, and $\mathrm{MCE}$ (based on the EFs of $\mathrm{CO}$ and $\mathrm{CO}_{2}$ ) are given. Here, we lumped all the EF data of A\&M2001-2009 for the three different biomes together. We performed simple linear regressions, with the $\mathrm{EF}$ as the dependent variable, and the different parameters that may control the EFs variability as the independent variables. Besides the correlation coefficients $(r), F$-values were calculated to test if the regression between the EF and the different driver data was significant (if the $F$-value exceeds the critical value of $F_{\text {crit }}$, it indicates a significant fit). We also performed a multivariate regression to construct a regression equation that combined the different parameters that accounted for most of the EF variability, in order to see if different variables combined performed better than the variables separately, and to be able to construct EFs for grid cells where no measurements were performed.

For CO EF we found the highest correlation with FTC $(r=0.49)$ and NDVI $(r=0.41)$. The corresponding $F$-values (66.2 and 7.0) exceeded the critical $\mathrm{F}$ value $\left(F_{\text {crit }}=\right.$ 6.7 ) for a significance level of 0.01 . When combining the different parameters in one regression equation, the correlation coefficient improved to 0.57 . For the $\mathrm{CH}_{4} \mathrm{EF}$, FTC $(r=0.58)$ and monthly precipitation $(r=0.53)$ were the most dominant parameters, and both correlations were significant at a level of 0.01 . Using the additional information of each parameter increased the correlation $(r=0.62)$. For $\mathrm{CO}_{2}$, FTC and monthly precipitation yielded the highest descriptive power $(r=-0.26$ and $r=-0.37$ ), similar to $\mathrm{CH}_{4}$. Despite the relatively low correlation coefficients, both fits were significant with $F$-values of 10.1 and 27.1. The multivariate regression equation gave a slightly higher correlation $(r=0.43)$. In general, the highest correlations were found for FTC, which is not surprising since this parameter covers the range from open grasslands, through savanna and woodlands, to tropical forest.

For MCE we found the highest correlation with monthly precipitation $(r=-0.52)$ and FTC $(r=-0.47)$, and both corresponding $F$-values (62.2 and 46.9) exceeded the critical $F$-value for a significance level of 0.01 . All environmental parameters combined, the correlation coefficient improved to 0.58. For MCE we performed a similar analysis using the dataset of Akagi et al. (2010), which is based on EF data measured in fresh plumes only, and therefore have not undergone significant photochemical processing. Overall, the correlations with the different environmental parameters did not improve compared to the EF dataset of A\&M2001-2009; a maximum correlation coefficient of 0.55 was found using all environmental data combined. This is not an indication that one dataset is preferred above the other one; for $\mathrm{CO}$ and $\mathrm{CO}_{2}$ it does not matter whether fresh or aged smoke is sampled. When translating our findings with regard to the MCE to other trace gases or aerosols, it may be preferable to use the Akagi et al. (2010) dataset because it consistently only takes those measurements focusing on fresh smoke into account, better representing initial emissions. In general, repeating the calculations but focusing on each individual biome yielded lower correlations than with all measurements lumped together. However, some of the relations found when using the full suite of data were still valid. For example, also within the savanna and grassland biome we found a negative correlation between FTC and MCE (or positive correlation between FTC and the CO EF) with an almost identical slope and offset as when using all measurements. Correlations between the EFs and the environmental data for the extratropical forest were poor. Possible explanations for these poor correlations are discussed in Sect. 4. Higher correlations between EFs and the driving variables were found when focusing on 
Table 1. Correlation coefficients $(r)$ and $F$-values $(F)$ for different environmental variables and $\mathrm{CO}, \mathrm{CH}_{4}, \mathrm{CO}_{2}$ EFs and MCE measurements. The correlation coefficients for the multivariate regression equation are also shown $(r$ combined). $n$ corresponds to the number of samples used, and $F$-values shown in italic indicate relations that did not exceed the critical $F$-value for a significance level of 0.01 .

\begin{tabular}{|c|c|c|c|c|c|c|c|c|}
\hline \multirow[t]{2}{*}{ Driver data } & \multicolumn{2}{|c|}{$\mathrm{CO}(n=216)$} & \multicolumn{2}{|c|}{$\mathrm{CH}_{4}(n=205)$} & \multicolumn{2}{|c|}{$\mathrm{CO}_{2}(n=169)$} & \multicolumn{2}{|c|}{$\operatorname{MCE}(n=169)$} \\
\hline & $r$ & $F$ & $r$ & $F$ & $r$ & $F$ & $r$ & $F$ \\
\hline Fraction Tree Cover & 0.49 & 66.2 & 0.58 & 104.3 & -0.26 & 10.1 & -0.47 & 46.9 \\
\hline Monthly Precipitation & 0.40 & 1.9 & 0.53 & 13.8 & -0.37 & 27.1 & -0.52 & 62.2 \\
\hline Mean Annual Precipitation & 0.29 & 3.2 & 0.33 & 4.4 & -0.13 & 0.4 & -0.15 & 4.1 \\
\hline Monthly Temperature & -0.13 & 0.1 & 0.03 & 0.1 & -0.13 & 2.7 & 0.01 & 0.2 \\
\hline Mean Annual Temperature & -0.23 & 1.1 & -0.24 & 2.2 & 0.16 & 0.9 & 0.29 & 15.9 \\
\hline Monthly NDVI & 0.41 & 7.0 & 0.39 & 0.5 & -0.22 & 0.2 & -0.46 & 46.1 \\
\hline Length dry season & 0.17 & 22.1 & -0.06 & 0.6 & 0.03 & 5.9 & -0.05 & 0.4 \\
\hline$r$ combined & 0.57 & & 0.62 & & 0.43 & & 0.58 & \\
\hline
\end{tabular}

specific locations, although it must be noted that the sample size of these correlations is relatively small. Figure 4a, $\mathrm{b}$, and c show correlations for respectively Brazilian deforestation fires and savanna fires in Australia (FTC vs. MCE), Brazilian deforestation fires (FTC vs. $\mathrm{CH}_{4} \mathrm{EF}$ ), and boreal fires in Alaska (precipitation vs. $\mathrm{CH}_{4} \mathrm{EF}$ ). A similar pattern occurred when focusing on vegetation types: correlations between MCE and $\mathrm{CH}_{4} \mathrm{EF}$ were relatively low when using all data lumped together (Fig. 2), and higher correlations were found in different individual studies, using a smaller sample size. Also, the extratropical forest data showed overall lower correlations than data for the savanna and tropical forest biome.

\subsection{Weighted EF averages}

Most large-scale biomass burning emission estimates are based on some combination of biomass or $\mathrm{C}$ combusted and EFs. These EFs are usually based on the arithmetic mean of a large number of measurements, most often using the work of A\&M2001-2009. It is not known, however, whether the measurements are representative of the whole biome. Regionally, there is substantial variation in the density of measurements. For example, nearly all tropical forest measurements are made in the Brazilian Amazon and Yucatan province of Mexico (Fig. 1), while information from other deforestation hot spots such as Bolivia and Indonesia is lacking. Different regional deforestation practices could in principle lead to variations in EFs, something that cannot be taken into account at the moment due to a lack of measurements. The same holds for the boreal region; according to the estimates of van der Werf et al. (2010), total C emissions from boreal Asia were almost 2.5 times as high as those from boreal North America in the last decade. Nevertheless nearly all the extratropical forest EF measurements were made in North America, and only one was conducted in boreal Asia (Fig. 1).
While there are large regional differences in the amount of sampling, the measurements do probe most of the climate conditions under which most fires occur (Fig. 5). To construct new weighted average EFs, we weighted each $\mathrm{EF}$ measurement location with its quantitative importance in the fire-climate window (Fig. 5). The size of the climatic window bins we used were $1{ }^{\circ} \mathrm{C}$ for mean annual temperature (MAT), $100 \mathrm{~mm}$ year $^{-1}$ for mean annual precipitation (MAP), and $2 \%$ for fraction tree cover (FTC). Table 2 gives an overview of these new calculated mean values per biome. The weighted values are at most $18 \%$ different from the arithmetic mean, but most often more similar (Table 2). Some differences, however, can be noticed: EFs of $\mathrm{CO}$ were 8\% below and 13\% above the mean of A\&M2001-2009 for tropical forest and extratropical forest measurements, respectively. $\mathrm{EFs}$ of $\mathrm{CH}_{4}$ were lower for each biome (16\% on average). $\mathrm{CO}_{2} \mathrm{EFs}$ were somewhat lower for savannas (1.5\%) and more variable for the tropical and extratropical biome.

The biome-average MCE obtained by weighting the individual measurement locations with their quantitative importance in the fire-climate window was $7 \%$ and $11 \%$ higher than the A\&M2001-2009 average for the tropical forest and extratropical biome, respectively. For the savanna biome the value was very close to the literature-average. Overall, our new calculated weighted averages for $\mathrm{CO}, \mathrm{CH}_{4}, \mathrm{CO}_{2} \mathrm{EFs}$ and MCE do not deviate much from the arithmetic mean of A\&M2001-2009, and are well within the range of uncertainty, especially when also taking the substantial uncertainties in the GFED fuel consumption estimates into account. This indicates that the measurements did not have a large bias due to sampling the wrong climatic conditions. However, it does not provide information of the representativeness of the measurement locations for the whole biome, which will be addressed next. 
Table 2. EFs of $\mathrm{CO}, \mathrm{CH}_{4}, \mathrm{CO}_{2}$ (in $\mathrm{g} \mathrm{kg}^{-1} \mathrm{DM}$ ), and MCE for the savanna and grassland (S), tropical forest (T), and extratropical forest (E) biome, weighted by carbon emissions and stratified by mean annual precipitation (MAP), mean annual temperature (MAT), fraction tree cover (FTC) bins, and a multivariate regression equation that combined different environmental variables (All variables, See Table 1). Biome-averaged arithmetic means of A\&M2001-2009 are also shown, with standard deviations in parenthesis. The results for the climatic window with the highest predictive power are shown in italic.

\begin{tabular}{|c|c|c|c|c|c|c|c|c|c|c|c|c|}
\hline & \multicolumn{3}{|c|}{$\mathrm{CO}\left(\mathrm{g} \mathrm{kg}^{-1} \mathrm{DM}\right)$} & \multicolumn{3}{|c|}{$\mathrm{CH}_{4}\left(\mathrm{~g} \mathrm{~kg}^{-1} \mathrm{DM}\right)$} & \multicolumn{3}{|c|}{$\mathrm{CO}_{2}\left(\mathrm{~g} \mathrm{~kg}^{-1} \mathrm{DM}\right)$} & \multicolumn{3}{|c|}{ MCE } \\
\hline & $\mathrm{S}$ & $\mathrm{T}$ & $\mathrm{E}$ & $\mathrm{S}$ & $\mathrm{T}$ & $\mathrm{E}$ & $\mathrm{S}$ & $\mathrm{T}$ & E & $\mathrm{S}$ & $\mathrm{T}$ & $\mathrm{E}$ \\
\hline MAP-MAT & 56 & 94 & 107 & 1.9 & 5.6 & 4.0 & 1624 & 1636 & 1588 & 0.948 & 0.919 & 0.903 \\
\hline FTC-MAT & 61 & 97 & 120 & 2.1 & 5.8 & 4.7 & 1622 & 1615 & 1529 & 0.944 & 0.915 & 0.889 \\
\hline FTC-MAP & 59 & 93 & 112 & 2.1 & 5.7 & 4.7 & 1627 & 1578 & 1565 & 0.949 & 0.917 & 0.899 \\
\hline All variables & 68 & 82 & 95 & 2.8 & 4.6 & 4.2 & 1647 & 1627 & 1648 & 0.941 & 0.930 & 0.915 \\
\hline A\&M2001-2009 & $\begin{array}{c}60 \\
(19)\end{array}$ & $\begin{array}{l}101 \\
(16)\end{array}$ & $\begin{array}{l}106 \\
(36)\end{array}$ & $\begin{array}{c}2.3 \\
(0.8)\end{array}$ & $\begin{array}{c}6.6 \\
(1.8)\end{array}$ & $\begin{array}{r}4.8 \\
(1.8)\end{array}$ & $\begin{array}{r}1646 \\
(99)\end{array}$ & $\begin{array}{r}1626 \\
(39)\end{array}$ & $\begin{array}{l}1572 \\
(106)\end{array}$ & 0.946 & 0.911 & 0.904 \\
\hline
\end{tabular}

\subsection{From a discrete towards a continuous classification scheme for EFs}

Following the work of Hoffa et al. (2003) and Ito and Penner (2005), we developed a non-vegetative classification scheme for EFs, driven by various environmental parameters. We performed a multivariate regression to construct an equation that combined the different environmental parameters (Table 1) for the $\mathrm{CO}, \mathrm{CH}_{4}$, and $\mathrm{CO}_{2} \mathrm{EFs}$, and the MCE. In Table 2 these new calculated mean values, weighted by the amount of biomass combusted in the 1997-2008 period, are given per biome. EFs of $\mathrm{CO}$ and $\mathrm{CH}_{4}$ were $\sim 13 \%$ and $\sim 22 \%$ higher than the biome-averaged values of A\&M20012009 for the savanna biome, and significantly lower for the tropical forest $\left(\sim 19 \%\right.$ for $\mathrm{CO}$ and $\sim 30 \%$ for $\left.\mathrm{CH}_{4}\right)$ and extratropical forest biome $\left(\sim 10 \%\right.$ for $\mathrm{CO}$ and $\sim 13 \%$ for $\left.\mathrm{CH}_{4}\right)$. $\mathrm{CO}_{2}$ EFs were the same for the savanna and tropical forest biome, and $\sim 5 \%$ higher for the extratropical forest.

Using the multivariate regression equation for MCE, which is mostly driven by monthly precipitation and FTC (Table 1), we constructed monthly MCE fields with a spatial resolution of $0.5^{\circ} \times 0.5^{\circ}$ for the years 1997-2008. In Fig. $6 \mathrm{a}$ the newly calculated MCE, weighted by the amount of monthly biomass combusted in the 1997-2008 period, is shown on a global scale. In general, tropical forest and boreal areas show lower MCE values compared to savanna regions. Spatial differences within savanna areas are obvious as well; woodland areas (for example, in Angola) have a relatively low MCE compared to areas where grasslands or open savannas are the dominant vegetation type, for example in South Africa or in the Australian interior. This difference is also seen directly in the measurements for miombo and dambo fires in e.g. Yokelson et al. (2003) and Sinha et al. (2004).

In Fig. $6 \mathrm{~b}$ the difference between our new "continuous" MCE and the biome-dependent MCE of A\&M2001-2009 is shown. The latter was constructed using the MOD12Q1 land cover map for 2001 (Friedl et al., 2002) to distribute the biome-specific MCEs over the globe. Areas where we predict a lower MCE, and which thus emit relatively more reduced gases $\left(\mathrm{CO}, \mathrm{CH}_{4}\right)$, are shown in blue. We expect that these grid cell specific MCEs are more reliable in the tropics than in boreal regions because more measurement locations were in the tropics. This may also be why FTC and monthly precipitation were the two most important parameters. In addition, the regression cannot deal with agricultural waste burning and peat burning regions. Regarding the savanna and grassland biome: we found the highest MCE in Australia (0.9466), followed by Southern Hemisphere Africa (0.9422), Northern Hemisphere South America (0.9403), and Southern Hemisphere South America (0.9386). Although differences in MCE are relatively small, they have a substantial influence on the amount of $\mathrm{CO}$ and other reduced trace gases released. For example, the small difference in MCE between Australia and Southern Hemisphere South America ( $\sim .9 \%)$ may imply a relatively large difference in the amount of $\mathrm{CO}$ emitted $(\sim 16 \%)$ if the total amount of $\mathrm{C}$ emitted as $\mathrm{CO}$ and $\mathrm{CO}_{2}$ is kept constant in both regions. An important next step is to implement these spatial and temporal EF and MCE scenarios into GFED, and quantify regional differences in trace gasses emitted.

\section{Discussion}

We evaluated a large body of available literature describing EF measurements conducted in different biomes throughout the world, and explored the relations between the EFs and global coarse-resolution datasets of environmental parameters that may influence EF variability. We chose to compare EFs with seven important control parameters for which global datasets were available and extended back to at least the early 1990s, except FTC which is only available for 

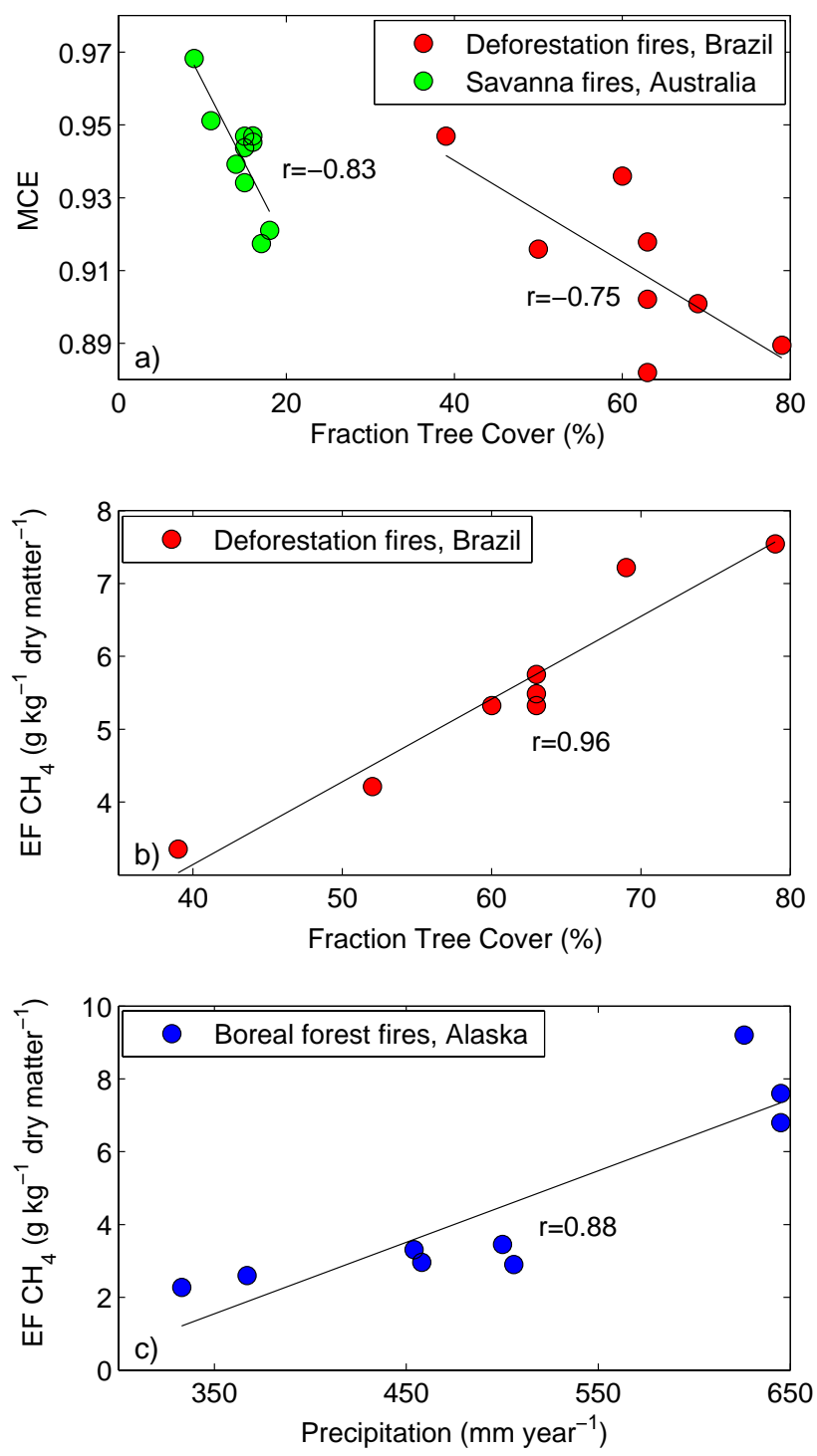

Fig. 4. Relations between environmental variables and EFs or MCE for selected regions. (a) FTC and MCE for savanna measurements in Australia (Hurst et al., 1994; Shirai et al., 2003) and tropical deforestation measurements in Brazil (Yokelson et al., 2007), (b) FTC and $\mathrm{CH}_{4} \mathrm{EF}$ for tropical deforestation measurements in Brazil (Yokelson et al., 2007), and (c) precipitation and $\mathrm{CH}_{4} \mathrm{EF}$ for extratropical forest measurements in Alaska (Laursen et al., 1992; Goode et al., 2000; Wofsy et al., 1992; Nance et al., 1993).

2002. These could account for up to about $33 \%(r=0.57)$, $38 \%(r=0.62), 19 \%(r=0.43)$, and $34 \%(r=0.58)$ of the variability for respectively $\mathrm{CO}, \mathrm{CH}_{4}, \mathrm{CO}_{2}$, and MCE. Several factors may account for the remaining variability and are discussed in Sects. 4.1-4.4. We discuss the new weighted biome-averaged EFs in Sect. 4.5, followed by recommendations for new EF campaigns (Sect. 4.6) and our future steps (Sect. 4.7).

\subsection{Uncertainty in environmental variables}

Monthly averages of coarse-resolution (regridded to $0.5^{\circ} \times 0.5^{\circ}$ ) data were used to assess fire emissions, FTC, precipitation, temperature, NDVI, and the length of the dry season for the different EF measurement locations. The use of spatial and temporal higher resolution data is preferred over lower resolution data, but detailed information on the location and date of the measurements was often lacking. Even if detailed information was given, a large number of EF measurements were conducted in the 1980s and early 1990s, for which period global datasets are often lacking at sufficient high resolution. Also in more recent periods data availability would limit a more detailed analysis: while FTC is available at $500-\mathrm{m}$ resolution, it is only available for the year 2002. And since fires likely impact FTC a multi-year product is required for consistency, so that - for example - each EF measurement can be linked to the FTC before the fire. To overcome these issues we have used the FTC aggregated to $0.5^{\circ} \times 0.5^{\circ}$ which will vary less from year to year. However, this approach will introduce errors in heterogeneous landscapes where the $0.5^{\circ} \times 0.5^{\circ}$ grid cell average may not be representative for local measurements, for example at the forest-pasture interface in active deforestation regions. These errors can be quantified as soon as annually resolved FTC data becomes available by using a subset of the available measurements in combination with a clear description of the measurement location. In addition to the issues outlined above, the environmental parameters have their own intrinsic uncertainty which was not included in our analysis, because the datasets have not undergone an official error assessment, with the exception of the precipitation data.

\subsection{Additional drivers of EF variability}

Although other environmental data (e.g. precipitation duration, fuel spacing, wind speed, and topography) may play an important role in fire characteristics and thus in the partitioning of trace gases emitted (e.g. Lobert et al., 1991), we could not take these factors into account because reliable information is not available from global datasets (see Sect. 4.1). Only few papers describing the measurements included detailed information on climatic and environmental conditions. Fuel composition may be another crucial factor for EF partitioning that was not taken into account here, and which may account for part of the variability not captured by the 7 parameters we could include because consistent information was available for all measurement locations. In the future, a combination of (1) more EF field measurements in undersampled areas, (2) better use of simultaneous satellite retrievals of trace gases (e.g., $\mathrm{CO}$ and $\mathrm{NO}_{2}$ ) in combination with detailed simulation of the fire plume rise and dispersion, and (3) the availability of higher spatial and temporal resolution satellite datasets may further improve our understanding 

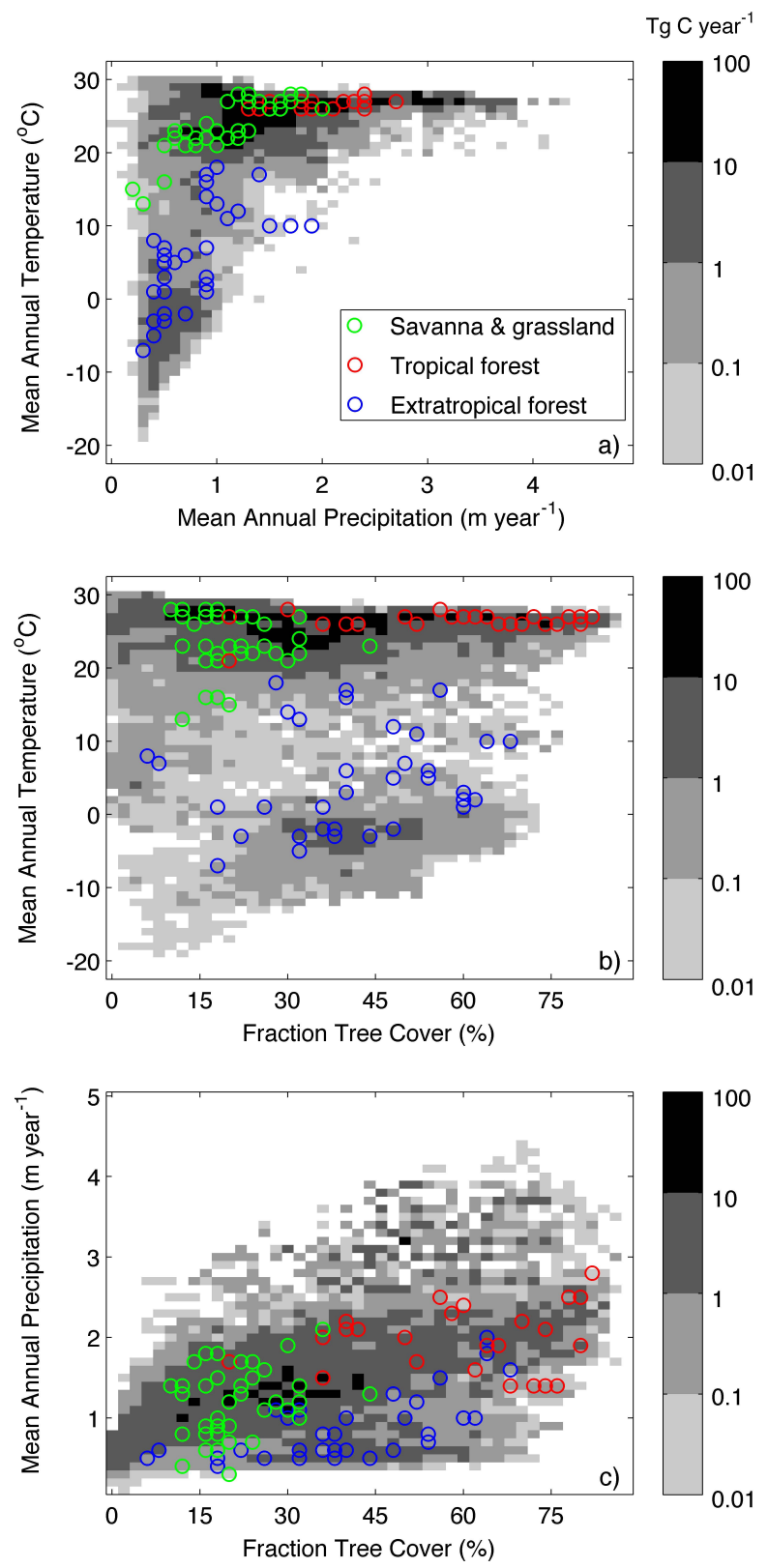

Fig. 5. GFED3.1 fire emissions in $\mathrm{TgC}_{\text {year }}{ }^{-1}$ (mean for 19972008) in a temperature versus precipitation (a), temperature versus FTC (b), and precipitation versus FTC (c) window overlain by EF measurements in the savanna and grassland (green), tropical forest (red), and extratropical forest (blue circles) biome. Temperature and precipitation were averaged over 1997-2008.

of how certain environmental parameters influence the EF variability for specific fires.

\subsection{Different measurement approaches and techniques}

Various analytical techniques have been used in recent field experiments, like non-dispersive infrared analysis (NDIR),
Fourier transform infrared spectroscopy (FTIR), and gas chromatography. Detailed descriptions of these different techniques can be found in the literature (Ward and Radke, 1993; Yokelson et al., 1999; Christian et al., 2004). For real-time concentration measurements, the analytical instruments must be close to the fire. A distinction can be made between ground-based (tower, mast) and airborne (aircraft, helicopter) measurements. Airborne measurements sample an integrated mixture of the emissions from both combustion types (smoldering and flaming). For ground-based measurements, which have a smaller footprint, the separation between smoldering and flaming combustion is more clear, but even here both processes occur simultaneously in a given patch at most times. Ground-based sampling probably oversamples the emissions during less vigorous phases of a fire and therefore remain closer to the ground, while airborne sampling may be biased towards emissions from the flaming phase that rise to higher altitudes (Andreae et al., 1996; Yokelson et al., 2008). Airborne measurements of chaparral vegetation in California (Laursen et al., 1992) were for example compared to ground-based measurements of the same vegetation type (Ward and Hardy, 1989), with overall lower EFs for $\mathrm{CO}(18 \%)$ and $\mathrm{CH}_{4}(60 \%)$, and higher for $\mathrm{CO}_{2}(5 \%)$. Yokelson et al. (2008) performed a similar analysis for tropical forest fires, and also found lower $\mathrm{EFs}$ of $\mathrm{CO}$ and $\mathrm{CH}_{4}$ for airborne measurements.

Although differences between measurement techniques are more important for sticky or reactive gases, the use of different techniques may have caused variations in $\mathrm{CO}, \mathrm{CH}_{4}$, and $\mathrm{CO}_{2}$ EFs measured in specific experiments. For example, SAFARI campaign measurements were conducted in South Africa and Zambia, and different research groups were involved to estimate EFs. Airborne Fourier transform infrared spectroscopy (AFTIR) was used by Yokelson et al. (2003) to measure EFs, while Sinha et al. (2003) used gas chromatography (GC). Both measuring techniques gave different EFs of $\mathrm{CO}, \mathrm{CH}_{4}$ and $\mathrm{CO}_{2}$, even though the location and timing of the burning event was identical. It must be noted though that the sample size for AFTIR was about 3 times as large as for the GC. Another example comes from the extratropical forest biome; the use of different analytical techniques led to a difference of $23 \%$ for $\mathrm{CO}, 8 \%$ for $\mathrm{CH}_{4}$, and $2 \%$ for $\mathrm{CO}_{2} \mathrm{EFs}$ for the same fires in North America (Hegg et al., 1990; Laursen et al., 1992).

\subsection{Flaming/smoldering assumptions}

The ratio between flaming and smoldering combustion of a fire is crucial for estimating the overall EF for different trace gases. In savanna fires, for example, flaming combustion dominates, and the EF for reduced species is relatively low compared to forest fires where the smoldering phase is often more important. The proportion of flaming and smoldering combustion can vary considerably also within fires in the same biome as a function of internal parameters (for example 


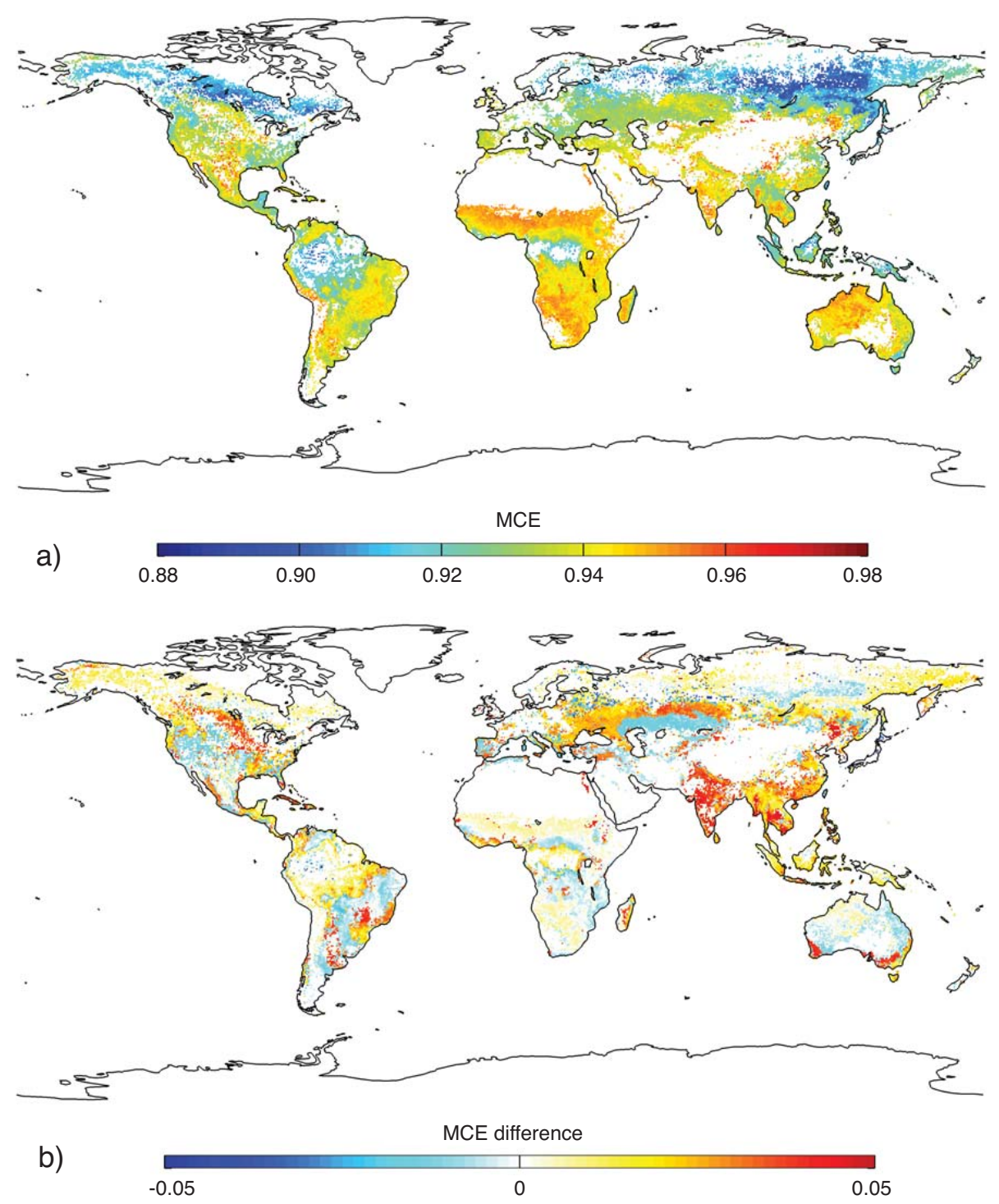

Fig. 6. (a) MCE based on a multivariate regression equation that combined different environmental variables (see Sect. 3.6), with a spatial resolution of $0.5^{\circ} \times 0.5^{\circ}$ and weighted by the monthly amount of biomass combusted according to GFED3.1 for the years 1997-2008. (b) Difference between (a) and the biome average MCE according to data of A\&M2001-2009. Fires in peatlands which have a very low MCE were neglected here.

moisture content). It may seem desirable to provide separate EFs for flaming and smoldering combustion, but this is not always possible given the data available. In the field, EFs are generally determined by averaging several instantaneous measurements from the fire. Most emissions are assumed to be a mixture of flaming and smoldering combustion, and it is essential that averaging of both phases is done correctly when the EF for an entire fire is sought. Sometimes the individual measurements are weighted according to the amount of fuel combusted in the time interval represented by the measurement (Ward and Hardy, 1991). This approach requires information that is only available in experimental fires in the laboratory or to a limited extent in the field, so often assumptions had to be made on the flaming to smoldering ratio leading to another source of uncertainty and potential to yield different EFs for similar smoke plumes.

Estimates of the relative importance of the flaming and smoldering phases vary in literature; for grass and shrub fires flaming combustion dominates and likely accounts for $80 \%$ to $90 \%$ of fuel consumption (Shea et al., 1996; Ward et al., 1996). For tropical forest and boreal fires smoldering combustion is more important. Bertschi et al. (2003), for example, assumed that the smoldering and flaming phases combusted equal amounts of biomass in boreal areas, and residual smoldering combustion (RSC) measurements of pure smoldering were combined with airborne measurements of Goode 
et al. (2000) to calculate an overall EF. The $\mathrm{CH}_{4} \mathrm{EF}$ more than doubled for boreal fires when RSC was included. Besides boreal areas, Bertschi et al. (2003) also measured EFs in African miombo; a flaming-smoldering ratio of 90-10 was taken, and AFTIR measurements from a study of Yokelson et al. (2003) were used to represent the flaming part. A change in these flaming-smoldering ratio's will impact the overall EF substantially, so the assumptions made by different authors are therefore important to consider (Yokelson et al., 1996).

A\&M2001-2009 made the assumption that when smoldering and flaming emissions were given separately in groundbased studies, the emissions were combined to represent the complete fire. For this purpose A\&M2001-2009 either used data on the fractions of fuel combusted in the smoldering and flaming stages provided in a given study, or, when this information was not available, typical values from other studies on the same type of fire were used.

\subsection{Weighted EF means}

The biome-averaged EF values of A\&M2001-2009 are widely used in the modeling community. These mean values may not be representative for the whole biome for many reasons as outlined in Sect. 3.2. We performed two levels of weighting. First, by placing the measurements in their climatic window (based on MAP, MAT, and FTC) we were able to weight the different measurements with the GFED3.1 $\mathrm{C}$ emissions estimates in the corresponding climatic window. The weighted EFs are within $6.7 \%, 7.9 \%$, and $13.2 \%$ of the arithmetic mean of A\&M2001-2009 for CO, 17.4\%, $15.2 \%$, and $6.7 \%$ for $\mathrm{CH}_{4}$, and $2.1 \%, 7.2 \%$, and $11.4 \%$ for the MCE for the savanna, tropical forest, and extratropical forest biome, respectively. The weighted $\mathrm{EFs}$ of $\mathrm{CO}_{2}$ were within $3 \%$ of the arithmetic mean for all three biomes. According to the linear regression results for the different environmental variables and $\mathrm{EFs}$, the climatic window with the most predictive power for $\mathrm{CO}, \mathrm{CH}_{4}, \mathrm{CO}_{2} \mathrm{EFs}$ and MCE together is based on FTC and MAP (Table 2). Based on the weighting by FTC and MAP, the EFs are systematically lower than the arithmetic mean of A\&M2001-2009, with a $8.7 \%, 3.7 \%$, and $2.1 \%$ decrease for $\mathrm{CH}_{4}$, and $1.2 \%, 1.5 \%$, and $0.4 \%$ for $\mathrm{CO}_{2}$, for the savanna, tropical forest, and extratropical forest biome, respectively. For CO the weighted EFs were lower than the arithmetic mean of A\&M2001-2009 for savanna and tropical forest (1.7\% and $7.9 \%)$, but higher for extratropical forest (3.8\%).

We used the different vegetation types that were defined by A\&M2001-2009, and based on these biomes (savanna and grassland, tropical forest, extratropical forest), we calculated new weighted EF averages. However, several measurements were conducted in vegetation types (for example chaparral in California and pine tree forest in Mexico) that cannot be clearly classified as savanna and grassland, tropical forest, or extratropical forest. While the EF measurements for the savanna and grassland and tropical forest biome were clustered in Fig. 5, the extratropical forest measurements show more variation (Fig. 5b). For a more specific EF average, it could be helpful to expand the amount of vegetation types, for example by adding a "temperate forest" and/or "chaparral" biome as in the Akagi et al. (2010) database.

Second, another level of weighting was performed by moving from a discrete classification based on a limited number of biome types, to stratifying EFs by vegetation density (FTC, NDVI) and climatic conditions (precipitation, temperature, length of dry season). Therefore, we developed a non-vegetative classification scheme for EFs (Fig. 6), driven by the different environmental parameters presented in Table 1. The global average MCE, weighted by the amount of biomass combusted in the 1997-2008 period, for the whole savanna biome was about $0.5 \%$ lower than the biome-averaged MCEs of A\&M2001-2009 and the weighted average MCEs for the different climate windows (Table 2). $\mathrm{CO}$ and $\mathrm{CH}_{4}$ EFs were $\sim 13 \%$ and $\sim 22 \%$ higher than the biome-averaged values of A\&M2001-2009 for the savanna biome, possibly linked to the underrepresentation of woodland fires in EF measurements. In addition, regional differences in MCE for the savanna biome were found, with the highest MCE for savanna and grasslands in Australia. For the savanna and grassland biome, nearly the same relation was found when we used all EF measurements combined, or when only using the EF measurements for the savanna and grassland biome. For this reason we have emphasized these results the most throughout the paper. For the other biomes, adjustments in our scheme may be needed in the future; 1) the extratropical forest may be somewhat biased to tropical regions where the majority of EF measurements were made, and 2) the coarse-resolution FTC, which is the most important driving variable, may introduce errors in the heterogeneous landscape of tropical deforestation regions. Even though deforestation fires usually occur in high FTC areas, surrounding areas that had been deforested will result in a lower FTC for the grid cell. Therefore, relations between EFs and environmental variables in the tropical forest biome may be driven more by the differences between the biomes, than the differences within the biome.

\subsection{Recommendations for future EF campaigns}

Ongoing studies aim to better quantify EFs. They often fill a niche, for example by measuring fuels for which information is lacking, like tropical peat fires. In addition, emphasis has switched towards understanding chemical processes within the fire plume. We have shown, however, that current available information on EFs is insufficient to substantially improve our understanding of the factors driving variability in EFs. By taking into account the following recommendations this situation may be improved:

Spatial representation: several areas are undersampled but are key emissions areas, most importantly Central Africa, boreal Asia, and Indonesia. Each of these regions likely has 
relatively high rates of emissions of reduced gases; more woodland burning in Central Africa compared to southern Africa where most savanna measurements were made, more ground fires in boreal Asia compared to boreal North America where most extratropical EFs were measured, and moister conditions and more peat burning in Indonesia compared to South America where most deforestation fire EFs were made.

Seasonality: to better understand the temporal variation of EFs in specific vegetation biomes, there is a need for measurements made over the full fire season, following Korontzi et al. (2003). In addition, the currently available measurements have placed too much weight to the months before (tropical forest) or the months before and after (grassland and savannas) the peak fire month and a stronger focus towards the local peak fire month would yield a better sample of the fire seasonality.

Fuel and ambient conditions: measuring and describing fuel composition, its moisture content, and ambient conditions such as wind speed and temperature may allow for a better understanding of the factors driving EFs, especially when multiple locations are visited with the same measurement protocol. This requires a more multi-disciplinary approach and calls for combining campaigns aiming to quantify biomass loads, CC, EFs, and satellite validation of e.g. hotspot detection efficiency and the accuracy of burned area.

\subsection{Future steps}

We found that stratifying EFs by vegetation density (FTC) and climatic conditions may better represent the large variability in EFs compared to a discrete classification based on a limited number of biome types. Based on these findings we aim to implement different EF scenario's into the GFED modeling framework. In combination with inverse modeling and space-based observations of trace gases, we will then investigate whether these new estimates better simulate atmospheric observations.

\section{Conclusions}

The partitioning of combusted biomass into trace gases and aerosols shows large variation in time and space. We assessed what fraction of this variability is correlated with coarse-resolution, globally available datasets including fraction tree cover (FTC), precipitation, and temperature. When combined, these datasets could account for up to about $40 \%(r=0.62)$ of the variability in emission factors (EFs). Uncertainties in driver data, the range of fuel C content, differences in measuring techniques, assumptions on weighting ratios of flaming and smoldering contributions, and insufficient information on the measurement locations may account for part of the remaining variability. In addition, we neglected driver variables such as fuel spacing, topography, and wind speed, which also may explain part of the variability.
We have calculated new average EFs for three biomes, by (1) weighting EFs by the amount of biomass combusted within operationally defined climate windows, and (2) building new maps of MCE using the relations between environmental variables and MCE, and weighting each grid cell by the amount of biomass combusted. Using the climatic window with the highest predictive power in the first level of weighting, weighted EFs for the biomes were lower than the arithmetic mean of A\&M2001-2009, with a 8.7\%, 3.7\%, and $2.1 \%$ decrease for $\mathrm{CH}_{4}$, and $1.2 \%, 1.5 \%$, and $0.4 \%$ for $\mathrm{CO}_{2}$, for the savanna, tropical forest, and extratropical forest biome, respectively. For $\mathrm{CO}$ the weighted EFs were lower than the arithmetic mean of A\&M2001-2009 for savanna and tropical forest (1.7\% and $7.9 \%)$, and higher for extratropical forest $(3.8 \%)$. Taking all levels of uncertainty into account, all of these differences are likely insignificant.

However, the second level of weighting using a nonvegetative classification $\mathrm{EF}$ scheme driven by different environmental parameters indicated that the MCE for savanna and grasslands may be lower than the MCE based on the arithmetic mean of all EF measurements. This would indicate higher emissions of $\mathrm{CO}$ and other reduced gases for the same amount of biomass burned for all global grasslands and savannas combined due to an underrepresentation of $\mathrm{EF}$ measurements in woodland burning regions. In addition, regional differences in MCE for the savanna biome were found, with the highest MCE (and thus lowest $\mathrm{CO} \mathrm{EF}$ ) for savannas and grasslands in Australia compared to Africa and SouthAmerica.

Currently, most of the literature describing EF measurements lacks a detailed description of the measurement site and ambient conditions during the experiment. This information is crucial to better understand the differences between the various measurements, and the correlation between largescale satellite data and ambient conditions. In addition, to better facilitate our ability to model MCE or EFs, more EF measurements should be performed in the peak fire months and in unsampled geographic areas. The development of a more accurate sampling protocol for the sampling and measurements of EFs in different vegetation types is another crucial step. For example, the work of Akagi et al. (2010), compiled EFs from studies that unambiguously measured initial emissions in fresh smoke and then attempted to calculate averages that reflect the combustion characteristics (to the extent possible) for a specific range of fire types.

A future step will be to implement our findings into the Global Fire Emission Database (GFED), and in combination with inverse modeling and space-based observations of trace gases, to investigate how a better representation of the spatial and temporal variability in EFs may improve our understanding of biomass burning emissions. 
Acknowledgements. We thank the emission factor measurement community for making their data publicly available, and M.O. (Andi) Andreae for his efforts to compile the available data and for keeping it up to date. We also greatly appreciate discussions with Bob Yokelson and Sheryl Akagi. Thijs van Leeuwen is supported by the Dutch User Support Programme from the Netherlands organization for scientific research (NWO) under program number GO/AO-11 and Guido van der Werf received funding from the EU Seventh Research Framework Programme (MACC project, contract number 218793).

Edited by: B. N. Duncan

\section{References}

Adler, R. F., Susskind, J., Huffman, G. J., Bolvin, D., Nelkin, E., Chang, A., Ferraro, R., Gruber, A., Xie, P.-P., Janowiak, J., Rudolf, B., Schneider, U., Curtis, S., and Arkin, P.: The version2 Global Precipitation Climatology Project (GPCP) Monthly Precipitation Analysis (1979-Present), J. Hydrometeorol., 4, 1147-1167, 2003.

Akagi, S. K., Yokelson, R. J., Wiedinmyer, C., Alvarado, M. J., Reid, J. S., Karl, T., Crounse, J. D., and Wennberg, P. O.: Emission factors for open and domestic biomass burning for use in atmospheric models, Atmos. Chem. Phys. Discuss., 10, 2752327602, doi:10.5194/acpd-10-27523-2010, 2010.

Andreae, M. O.: Soot carbon and excess fine potassium: Longrange transport of combustion-derived aerosols, Science, 220, 1148-1151, 1983.

Andreae, M. O.: The influence of tropical biomass burning on climate and the atmospheric environment, in Biogeochemistry of Global Change: Radiatively Active Trace Gases, edited by: Oremland, R. S., 113-150, Chapman and Hall, New York, USA, 1993.

Andreae, M. O. and Merlet, P.: Emission of trace gases and aerosols from biomass burning, Global Biogeochem. Cy., 15(4), 955-966, 2001.

Andreae, M. O., Atlas, E., Cachier, H., Cofer, W. R., Harris, G. W., Helas, G., Koppman, R., Lacaux, J.-P., and Ward, D. E.: Trace gas and aerosol emissions from savanna fires, in Biomass Burning and Global Change, edited by: Levine, J. S., 278-295, MIT Press, Cambridge, Mass., 1996.

Arellano, A. F., Kasibhatla, P. S., Giglio, L., van der Werf, G. R., and Randerson, J. T.: Top-down estimates of global CO sources using MOPITT measurements, Geophys. Res. Lett., 31, L01104, doi:10.1029/2003GL018609, 2004.

Ayers, G. P. and Gillett, R. W.: Isoprene emissions from vegetation and hydrocarbon emissions from bushfires in tropical Australia, J. Atmos. Chem., 7, 177-190, 1988.

Bertschi, I., Yokelson, R. J., Ward, D. E., Babbitt, R. E., Susott, R. A., Goode, J. G., and Hao, W. M.: Trace gas and particle emissions from fires in large diameter and belowground biomass fuels, J. Geophys. Res., 108, 8472, doi:10.1029/2002JD002100, 2003.

Bowman, D. M. J. S., Balch, J. K., Artaxo, P., Bond, W. J., Carlson, J. M., Cochrane, M. A., D’Antonio, C. M., DeFries, R. S., Doyle, J. C., Harrison, S. P., Johnston, F. H., Keeley, J. E., Krawchuk, M. A., Kull, M. A., Marston, J. B., Moritz, M. A., Prentice, I. C.,
Roos, C. I., Scott, A. C., Swetnam, T. W., van der Werf, G. R., and Pyne, S. J.: Fire in the Earth system, Science, 324, 481-484, doi:10.1126/science.1163886, 2009.

Bradshaw, L. S., Deeming, J. E., Burgan, R. E., and Cohen, J. D.: The 1978 National Fire-Danger Rating System: technical documentation. General Technical Report INT-169. Ogden, UT: US Department of Agriculture, Forest Service, Intermountain Forest and Range Experiment Station, 1978.

Burling, I. R., Yokelson, R. J., Griffith, D. W. T., Johnson, T. J., Veres, P., Roberts, J. M., Warneke, C., Urbanski, S. P., Reardon, J., Weise, D. R., Hao, W. M., and de Gouw, J.: Laboratory measurements of trace gas emissions from biomass burning of fuel types from the southeastern and southwestern United States, Atmos. Chem. Phys., 10, 11115-11130, doi:10.5194/acp10-11115-2010, 2010.

Chandler, C., Cheney, P., Thomas, P., Trabaud, L., and Williams, D.: Fire in Forestry, 1, Wiley, New York, USA, 1983.

Chang, D. and Song, Y.: Comparison of L3JRC and MODIS global burned area products from 2000 to 2007, J. Geophys. Res., 114, D16106, doi:10.1029/2008JD011361, 2009.

Chen, L.-W. A., Verburg, P., Shackelford, A., Zhu, D., Susfalk, R., Chow, J. C., and Watson, J. G.: Moisture effects on carbon and nitrogen emission from burning of wildland biomass, Atmos. Chem. Phys., 10, 6617-6625, doi:10.5194/acp-10-66172010, 2010.

Christian, T. J., Kleiss, B., Yokelson, R. J., Holzinger, R., Crutzen, P. J., Hao, Saharjo, B. H., and Ward, D. E.: Comprehensive laboratory measurements of biomass-burning emissions: 1. Emissions from Indonesian, African, and other fuels, J. Geophys. Res., 108(D23), 4719, doi:10.1029/2003JD00304, 2003.

Christian, T. J., Kleiss, B., Yokelson, R. J., Holzinger, R., Crutzen, P. J., Hao, W. M., Shirai, T., and Blake, D. R.: Comprehensive laboratory measurements of biomass-burning emissions: 2. First intercomparison of open-path FTIR, PTRMS, and GC-MS/FID/ECD, J. Geophys. Res., 109, D02311, doi:10.1029/2003JD003874, 2004.

Christian, T. J., Yokelson, R. J., Carvalho Jr., J. A., Griffith, D. W. T., Alvarado, E. C., Santos, J. C., Gomes Soares Neto, T., Gurgel Veras, C. A., and Hao, W. M.: The tropical forest and fire emissions experiment: Trace gases emitted by smoldering logs and dung from deforestation and pasture fires in Brazil, J. Geophys. Res., 112, D18308, doi:10.1029/2006JD008147, 2007.

Cofer, W. R., Winstead, E. L., Stocks, B. J., Goldammer, J. G., and Cahoon, D. R.: Crown fire emissions of $\mathrm{CO}_{2}, \mathrm{CO}, \mathrm{H}_{2}, \mathrm{CH}_{4}$, and TNMHC from a dense jack pine boreal forest fire, Geophys. Res. Lett., 25(21), 3919-3922, 1998.

Crutzen, P. J., Heidt, L. E., Krasnec, J. P., Pollock, W. H., and Seiler, W.: Biomass burning as a source of atmospheric gases $\mathrm{CO}, \mathrm{H}_{2}$, $\mathrm{N}_{2} \mathrm{O}, \mathrm{NO}, \mathrm{CH}_{3} \mathrm{CL}$, and COS, Nature, 282, 253-256, 1979.

Crutzen, P. J. and Andreae, M. O.: Biomass burning in the tropics: Impact on atmospheric chemistry and biogeochemical cycles, Science, 250, 1669-1678, 1990.

Delmas, R. and Servant, J.: The origins of sulfur compounds in the atmosphere of a zone of high productivity (Gulf of Guinea), J. Geophys. Res., 87, 11019-11026, 1982.

Delmas, R., Lacaux, J. P., and Brocard, D.: Determination of biomass burning emission factors: Methods and results, Environ. Monit. Assess., 38, 181-204, 1995.

Edwards, D. P., Emmons, L. K., Hauglustaine, D. A., Chu, D. A., 
Gille, J. C., Kaufman, Y. J., Pétron, G., Yurganov, L. N., Giglio, L., Deeter, M. N., Yudin, V., Ziskin, D. C., Warner, J., Lamarque, J.-F., Francis, G. L., Ho, S. P., Mao, D., Chen, J., Grechko, E. I., and Drummond, J. R.: Observations of carbon monoxide and aerosols from the Terra satellite: Northern Hemisphere variability, J. Geophys. Res., 109, D24202, doi:10.1029/2004JD004727, 2004.

FIRESCAN Science Team: Fire in Ecosystems of Boreal Eurasia: The Bor Forest Island Fire Experiment Fire Research Campaign Asia-North (FIRESCAN), in Biomass Burning and Global Change, edited by: Levine, J. S., 848-873, MIT Press, Cambridge, Mass., 1996.

Fishman, J., Watson, C. E., Larsen, J. C., and Logan, J. A.: Distribution of tropospheric ozone determined from satellite data, J. Geophys. Res., 95(D4), 3599-3617, 1990.

Fishman, J., Hoell Jr., J. M., Bendura, R. D., McNeal, R. J., and Kirchhoff, V. W. J. H.: NASA GTE TRACE A Experiment (September-October 1992): Overview, J. Geophys. Res., 101, D19, 23865-23879, 1996.

Friedl, M. A., McIver, D. K., Hodges, J. C. F., Zhang, X. Y., Muchoney, D., Strahler, A. H., Woodcock, C. E., Gopal, S., Schneider, A., Cooper, A., Baccini, A., Gao, A., and Schaaf, C.: Global land cover mapping from MODIS: algorithms and early results, Remote Sens. Environ., 83, 287-302, 2002.

Frost, P.: The ecology of miombo woodlands, in The Miombo in Transition: Woodlands and Welfare in Africa, edited by: Campbell, B., 11-58, Cent. for Int. For. Res., Bogor, Indonesia, 1996.

Giglio, L., van der Werf, G. R., Randerson, J. T., Collatz, G. J., and Kasibhatla, P.: Global estimation of burned area using MODIS active fire observations, Atmos. Chem. Phys., 6, 957974, doi:10.5194/acp-6-957-2006, 2006.

Giglio, L., Csiszar, I., and Justice, C. O.: Global distribution and seasonality of active fires as observed with the Terra and Aqua Moderate Resolution Imaging Spectroradiometer (MODIS) sensors, J. Geophys. Res., 111, G02016, doi:10.1029/2005JG000142, 2006.

Giglio, L., Randerson, J. T., van der Werf, G. R., Kasibhatla, P. S., Collatz, G. J., Morton, D. C., and DeFries, R. S.: Assessing variability and long-term trends in burned area by merging multiple satellite products, Biogeosciences, 7, 1171-1186, doi:10.5194/bg-7-1171-2010, 2010.

Gloudemans, A. M. S., Krol, M. C., Meirink, J. F., de Laat, A. T. J., van der Werf, G. R., Schrijver, H., van den Broek, M. M. P., and Aben, I.: Evidence for long-range transport of carbon monoxide in the Southern Hemisphere from SCIAMACHY observations, Geophys. Res. Lett., 33, L16807, doi:10.1029/2006GL026804, 2006.

Goode, J. G. and Yokelson, R. J.: Measurements of excess $\mathrm{O}_{3}$, $\mathrm{CO}_{2}, \mathrm{CO}, \mathrm{CH}_{4}, \mathrm{C}_{2} \mathrm{H}_{4}, \mathrm{C}_{2} \mathrm{H}_{2}, \mathrm{HCN}, \mathrm{NO}, \mathrm{NH}_{3}, \mathrm{HCOOH}$, $\mathrm{CH}_{3} \mathrm{COOH}, \mathrm{HCHO}$, and $\mathrm{CH}_{3} \mathrm{OH}$ in 1997 Alaskan biomass burning plumes by airborne Fourier transform infrared spectroscopy (AFTIR), J. Geophys. Res., 105(D17), 22147-22166, doi:10.1029/2000JD900287, 2000.

Hansen, J., Ruedy, R., Glascoe, J., and Sato, M.: GISS analysis of surface temperature change, J. Geophys. Res., 104(D24), 3099731022, 1999.

Hansen, J., Ruedy, R., Sato, M., Imhoff, M., Lawrence, W., Easterling, D., Peterson, T., and Karl, T.: A closer look at United States and global surface temperature change, J. Geophys. Res., 106,
23947-23963, 2001.

Hansen, M. C., DeFries, R. S., Townshend, J. R. G., Carroll, M., Dimiceli, C., and Sohlberg, R. A.: Global percent tree cover at a spatial resolution of 500 meters: first results of the MODIS vegetation continuous fields algorithm, Earth Interact., 7, 10, doi:10.1175/1087-3562, 2003.

Hao, W. M. and Ward, D. E.: Methane production from global biomass burning, J. Geophys. Res., 98, 20657-20661, 1993.

Hegg, D. A., Radke, L. F., Hobbs, P. V., Rasmussen, R. A., and Riggan, P. J.: Emissions of some trace gases from biomass fires, J. Geophys. Res., 95, 5669-5675, 1990.

Hobbs, P. V., Reid, J. S., Herring, J. A., Nance, J. D., Weiss, R. E., Ross, J. L., Hegg, D. A., Ottmar, R. D., and Louisse, C.: Particle and trace-gas measurements in the smoke from prescribed burns of forest products in the Pacific Northwest, in Biomass Burning and Global Change, edited by: Levine, J. S., 697-715, MIT Press, Cambridge, Mass., 1996.

Hoffa, E. A., Ward, D. E., Hao, W. M., Susott, R. A., and Wakimoto, R. H.: Seasonality of carbon emissions from biomass burning in a Zambian savanna, J. Geophys. Res.-Atmos., 104(D11), 1384113853, doi:10.1029/1999JD900091, 1999.

Huffman, G. J., Adler, R. F., Morrissey, M., Bolvin, D. T., Curtis, S., Joyce, R., McGavock, B., and Susskind, J.: Global precipitation at one-degree daily resolution from multi-satellite observations, J. Hydrometeorol., 2, 36-50, 2001.

Hurst, D. F., Griffith, W. T., Carras, J. N., Williams, D. J., and Fraser, P. J.: Measurements of trace gases emitted by Australian savanna fires during the 1990 dry season, J. Atmos. Chem., 18, 33-56, 1994.

Janhäll, S., Andreae, M. O., and Pöschl, U.: Biomass burning aerosol emissions from vegetation fires: particle number and mass emission factors and size distributions, Atmos. Chem. Phys., 10, 1427-1439, doi:10.5194/acp-10-1427-2010, 2010.

Ito, A. and Penner, J. E.: Estimates of CO emissions from open biomass burning in southern Africa for the year 2000, J. Geophys. Res., 110, D19306, doi:10.1029/2004JD005347, 2005.

Kaufman, Y. J., Hobbs, P. V., Kirchhoff, V. W. J. H., Artaxo, P., Remer, L. A., Holben, B. N., King, M. D., Ward, D. E., Prins, E. M., Longo, K. M., Mattos, L. F., Nobre, C. A., Spinhirne, J. D., Ji, Q., Thompson, A. M., Gleason, J. F., Christopher, S. A., and Tsay, S.-C.: Smoke, Clouds, and Radiation-Brazil (SCARB) experiment, J. Geophys. Res., 103(D24), 31783-31808, 1998.

Kopacz, M., Jacob, D. J., Fisher, J. A., Logan, J. A., Zhang, L., Megretskaia, I. A., Yantosca, R. M., Singh, K., Henze, D. K., Burrows, J. P., Buchwitz, M., Khlystova, I., McMillan, W. W., Gille, J. C., Edwards, D. P., Eldering, A., Thouret, V., and Nedelec, P.: Global estimates of CO sources with high resolution by adjoint inversion of multiple satellite datasets (MOPITT, AIRS, SCIAMACHY, TES), Atmos. Chem. Phys., 10, 855-876, doi:10.5194/acp-10-855-2010, 2010.

Korontzi, S., Ward, D. E., Susott, R. A., Yokelson, R. J., Justice, C. O., Hobbs, P. V., Smithwick, E. A. H., and Hao, W. M.: Seasonal variation and ecosystem dependence of emission factors for selected trace gases and $\mathrm{PM}_{2.5}$ for southern African savanna fires, J. Geophys. Res., 108(D24), 4758, doi:10.1029/2003JD003730, 2003.

Lacaux, J. P., Brustet, J. M., Delmas, R., Menaut, J. C., Abbadie, L., Bonsang, B., Cachier, H., Baudet, J., Andreae, M. O., and Helas, G.: Biomass burning in the Tropical Savannas of Ivory 
Coast: An overview of the field experiment Fire Of Savannas (FOS/DECAFE 91), J. Atmos. Chem., 22, 195-216, 1995.

Langenfelds, R. L., Francey, R. J., Pak, B. C., Steele, L. P., Lloyd, J., Trudinger, C. M., and Allison, C. E.: Interannual growth rate variations of atmopsheric $\mathrm{CO}_{2}$ and its $\mathrm{d}^{13} \mathrm{C}, \mathrm{H}_{2}, \mathrm{CH}_{4}$, and CO between 1992 and 1999 linked to biomass burning, Global Biogeochem. Cycles, 16(3), 1048, doi:10.1029/2001GB001466, 2002.

Laursen, K. K., Hobbs, P. V., Radke, L. F., and Rasmussen, R. A.: Some trace gas emissions from North American biomass fires with an assessment of regional and global fluxes from biomass burning, J. Geophys. Res., 97, D18, 20687-20701, 1992.

Lindesay, J. A., Andreae, M. O., Goldammer, J. G., Harris, G., Annegarn, H. J., Garstang, M., Scholes, R. J., and Wilgen, B. W.: International Geosphere-Biosphere Programme/International Global Atmospheric Chemistry SAFARI92 field experiment: Background and overview, J. Geophys. Res., 101(D19), 23521-23530, 1996.

Lobert, J. M., Scharffe, D. H., Kuhlbusch, T. A., Seuwen, R., Warneck, P., and Crutzen, P. J.: Experimental evaluation of biomass burning emissions: nitrogen and carbon-containing compounds, in Global Biomass Burning, edited by Levine, J., 289-304, MIT Press., Cambridge, Mass., 1991.

Lobert, J. M. and Warnatz, J.: Emissions from the combustion process in vegetation, in: Fire in the Environment: The Ecological, Atmospheric, and Climatic Importance of Vegetation Fires, edited by: Crutzen, P. J. and Goldammer, J. G., John Wiley, New York, USA, 15-37, 1993.

McMeeking, G. R., Kreidenweis, S. M., Baker, S., Carrico, C. M., Chow, J. C., Collett Jr., J. L., Hao, W. M., Holden, A. S., Kirchstetter, T. W., Malm, W. C., Moosmüller, H., Sullivan, A. P., and Wold, C. E.: Emissions of trace gases and aerosols during the open combustion of biomass in the laboratory, J. Geophys. Res., 114, D19210, doi:10.1029/2009JD011836, 2009.

Morton, D. C., DeFries, R. S., Shimabukuro, Y. E., Anderson, L. O., Arai, E., Espirito-Santo, F. D., Freitas, R., and Morisette, J.: Cropland expansion changes deforestation dynamics in the southern Brazilian Amazon, P. Natl. Acad. Sci. USA, 103(39), 14637-14641, doi:10.1073/pnas.0606377103, 2006.

Nance, J. P., Hobbs, P. V., and Radke, L. F.: Airborne measurements of gases and particles from an Alaskan wildfire, J. Geophys. Res., 98, 14873-14882, 1993.

New, M., Hulme, M., and Jones, P.: Representing twentieth-century space-time climate variability. Part 1: Development of a 1961-90 mean monthly terrestrial climatology, J. Climate, 12, 829-856, 1999.

Peterson, T. C. and Vose, R. S.: An overview of the Global Historical Climatology Network Temperature Database, B. Am. Meteorol. Soc., 78, 2837-2849, 1997.

Plummer, S., Arino, O., Simon, M., and Steffen, W.: Establishing an earth observation product service for the terrestrial carbon community: the GLOBCARBON initiative, Mitigation and Adaptation Strategies for Global Change, 11(1), 97-111, doi:10.1007/s11027-006-1012-8, 2006.

Radke, L. F., Stith, J. L., Hegg, D. A., and Hobbs, P. V.: Airborne studies of particles and gases from forest fires, J. Air Pollut. Control. Assoc., 28, 30-34, 1978.

Radke, L. F., Lyons, J. H., Hobbs, P. V., Hegg, D. A., Sandberg, D. V., and Ward, D. E.: Airborne monitoring and smoke characteri- zation of prescribed fires on forest lands in Western Washington and Oregon, Tech. Rep. PNW-GTR-251, 88 pp., For. Serv., U.S. Dep. Of Agric., Portland, Ore., 1990.

Roy, D. P. and Boschetti, L.: Southern Africa validation of the MODIS, L3JRC, and GlobCarbon burned-area products, IEEE Trans. Geosci. Remote Sensing, 47(4), 1031-1044, doi:10.1109/TGRS.2008.2009000, 2009.

Roy, D. P., Boschetti, L., Justice, C. O., and Ju, J.: The collection 5 MODIS burned area product - Global evaluation by comparison with the MODIS active fire product, Remote Sens. Environ., 112(9), 3690-3707, doi:10.1016/j.rse.2008.05.013, 2008.

Seiler, W. and Crutzen, P. J.: Estimates of gross and net fluxes of carbon between the biosphere and the atmosphere from biomass burning, Clim. Change, 2, 207-247, 1980.

Shea, R. W., Shea, B. W., Kauffman, J. B., Ward, D. E., Haskins, C. I., and Scholes, M. C.: Fuel biomass and combustion factors associated with fires in savanna ecosystems of South Africa and Zambia, J. Geophys. Res., 101(D19), 23551-23568, 1996.

Shirai, T., Blake, D. R., Meinardi, S., Rowland, F. S., RussellSmith, J., Edwards, A., Kondo, Y., Koike, M., Kita, K., Machida, T., Takegawa, N., Nishi, N., Kawakami, S., and Ogawa, T.: Emission estimates of selected volatile organic compounds from tropical savanna burning in northern Australia, J. Geophys. Res., 108(D3), 8406, doi:10.1029/2001JD000841, 2003.

Sinha, P., Hobbs, P. V., Yokelson, R. J., Bertschi, I. T., Blake, D. R., Simpson, I. J., Gao, S., Kirchstetter, T. W., and Novakov, T.: Emissions of trace gases and particles from savanna fires in Southern Africa, J. Geophys. Res., 108, 8487, doi:10.1029/2002JD002325, 2003.

Sitch, S., Cox, P. M., Collins, W. J., and Huntingford, C.: Indirect radiative forcing of climate change through ozone effects on the land-carbon sink, Nature, 448, 791-794, doi:10.1038/nature06059, 2007.

Susott, R. A., Olbu, G. J., Baker, S. P., Ward, W. E., Kauffman, J. B., and Shea, R.: Carbon, hydrogen, nitrogen, and thermogravimetric analysis of tropical ecosystem biomass, in: Biomass Burning and Global Change, edited by: Levine, J. S., 350-360, MIT Press, Cambridge, Mass., 1996.

Swap, R. J., Annegarn, H. J., Suttles, J. T., Haywood, J., Helmlinger, M. C., Hely, C., Hobbs, P. V., Holben, B. N., Ji, J., King, M. D., Landmann, T., Maenhaut, W., Otter, L., Pak, B., Piketh, S. J., Platnick, S., Privette, J., Roy, D., Thompson, A. M., Ward, D., and Yokelson, R. J.: The Southern African Regional Science Initiatve (SAFARI 2000): Overview of the dry season field campaign, South African J. Sci., 98, 125-130, 2002.

Tansey, K., Grégoire, J.-M., Pereira, J. M. C., Defourny, P., Leigh, R., Pekel, J.-F., Barros, A., Silva, J., van Bogaert, E., Bartholomé, E., and Bontemps, S.: L3JRC-A global, multiyear (2000-2007) burnt area product (1 km resolution and daily time steps), Remote Sensing and Photogrammetry Society Annual Conference 2007, Newcastle upon Tyne, UK, 2007.

Tucker, C. J., Pinzon, J. E., Brown, M. E., Slayback, D. A., Pak, E. W., and Mahoney, R.: An extented AVHRR 8-km NDVI data set compatible with MODIS and SPOT vegetation NDVI data, Int. J. Remote Sens., 26, 4485-4498, 2005.

van der Werf, G. R., Randerson, J. T., Giglio, L., Collatz, G. J., Kasibhatla, P. S., and Arellano Jr., A. F.: Interannual variability in global biomass burning emissions from 1997 to 2004, Atmos. Chem. Phys., 6, 3423-3441, doi:10.5194/acp-6-3423-2006, 
2006.

van der Werf, G. R., Randerson, J. T., Giglio, L., Collatz, G. J., Mu, M., Kasibhatla, P. S., Morton, D. C., DeFries, R. S., Jin, Y., and van Leeuwen, T. T.: Global fire emissions and the contribution of deforestation, savanna, forest, agricultural, and peat fires (19972009), Atmos. Chem. Phys., 10, 11707-11735, doi:10.5194/acp10-11707-2010, 2010.

Ward, D. E. and Hardy, C. C.: Emissions from prescribed chaparral burning, paper presented at Annual Meeting, Air and Waste Management Association, Anaheim, California, 1989.

Ward, D. E. and Hardy, C. C.: Smoke emissions from wildland fires, Environ. Int., 17, 117-134, 1991.

Ward, D. E. and Radke, L. F.: Emission measurements from vegetation fires: A comparative evaluation of methods and results, in Fire in the Environment: The Ecological, Atmospheric, and Climatic Importance of Vegetation Fires, edited by: Crutzen, P. J. and Goldammer, J. G., John Wiley and Sons Ltd., 53-76, 1993.

Ward, D. E., Nelson, R. M., and Adams, D. F.: Forest fire smoke plume documentation, paper presented at the 77th Annual meeting, Air Pollut. Control Assoc., Air and Waste Manage. Assoc., Pittsburgh, Pa., 1979.

Ward, D. E., Susott, R. A., Kauffman, J. B., Babbitt, R. E., Cummings, D. L., Dias, B., Holben, B. N., Kaufman, Y. J., Rasmussen, R. A., and Setzer, A. W.: Smoke and fire characteristics for cerrado and deforestation burns in Brazil: BASE-B experiment, J. Geophys. Res., 97(D13), 14601-14619, doi:10.1029/92JD01218, 1992.

Ward, D. E., Hao, W. M., Susott, R. A., Babbitt, R. A., Shea, R. W., Kauffman, J. B., and Justice, C. O.: Effect of fuel composition on combustion efficiency and emission factors for African savanna ecosystems, J. Geophys. Res., 101(D19), 23569-23576, 1996.

Williams, R. J., Gill, A. M., and Moore, P. H. R.: Seasonal changes in fire behaviour in a tropical savanna in northern Australia, Int. J. Wildland Fire, 8(4), 227-239, 1998.
Wofsy, S. C., Sachse, G. W., Gregory, G. L., Blake, D. R., Bradshaw, J. D., Sandholm, S. T., Singh, H. B., Barrick, J. A., Harriss, R. C., Talbot, R. W., Shipham, M. A., Browell, E. V., Jacob, D. J., and Logan, J. A.: Atmospheric chemistry in the Arctic and Subarctic: influence of natural fires, industrial emissions, and stratospheric inputs, J. Geophys. Res., 97, 16731-16746, 1992.

Wooster, M. J. and Zhang, Y. H.: Boreal forest fires burn less intensely in Russia than in North America, Geophys. Res. Lett., 31, L20505, doi:10.1029/2004GL020805, 2004.

Yokelson, R. J., Griffith, D. W. T., and Ward, D. E.: Openpath Fourier transform infrared studies of large-scale laboratory biomass fires, J. Geophys. Res., 101(D15), 21067-21080, 1996.

Yokelson, R. J., Susott, R., Ward, D. E., Reardon, J., and Griffith, D. W. T.: Emissions from smoldering combustion of biomass measured by open-path Fourier transform infrared spectroscopy, J. Geophys. Res., 102(D15), 18865-18877, 1997.

Yokelson, R. J., Goode, J. G., Ward, D. E., Susott, R. A., Babbitt, R. E., Wade, D. D., Bertschi, I. T., Griffith, D. W. T., and Hao, W. M.: Emissions of formaldehyde, acetic acid, methanol, and other trace gases from biomass fires in North Carolina measured by airborne Fourier transform infrared spectroscopy, J. Geophys. Res., 104(D23), 30109-30125, doi:10.1029/1999JD900817, 1999.

Yokelson, R. J., Bertschi, I. T., Christian, T. J., Hobbs, P. V., Ward, D. E., and Hao, W. M.: Trace gas measurements in nascent, aged, and cloud-processed smoke from African savanna fires by airborne Fourier transform infrared spectroscopy (AFTIR), J. Geophys. Res., 108(D13), 8478, doi:10.1029/2002JD002322, 2003.

Yokelson, R. J., Karl, T., Artaxo, P., Blake, D. R., Christian, T. J., Griffith, D. W. T., Guenther, A., and Hao, W. M.: The Tropical Forest and Fire Emissions Experiment: overview and airborne fire emission factor measurements, Atmos. Chem. Phys., 7, 5175-5196, doi:10.5194/acp-7-5175-2007, 2007.

Yokelson, R. J., Christian, T. J., Karl, T. G., and Guenther, A.: The tropical forest and fire emissions experiment: laboratory fire measurements and synthesis of campaign data, Atmos. Chem. Phys., 8, 3509-3527, doi:10.5194/acp-8-3509-2008, 2008. 